QA: QA

TDR-WER-NU-000002 REV 00 ICN 01

December 2001

\title{
Subsurface Contamination Control
}

By

YuChien Yuan

Prepared for:

U.S. Department of Energy

Yucca Mountain Site Characterization Office

P.O. Box 30307

North Las Vegas, Nevada 89036-0307

Prepared by:

Bechtel SAIC Company, LLC

1180 Town Center Drive

Las Vegas, Nevada 89144

Under Contract Number

DE-AC08-01RW12101 


\section{DISCLAIMER}

This report was prepared as an account of work sponsored by an agency of the United States Government. Neither the United States Government nor any agency thereof, nor any of their employees, nor any of their contractors, subcontractors or their employees, makes any warranty, express or implied, or assumes any legal liability or responsibility for the accuracy, completeness, or any third party's use or the results of such use of any information, apparatus, product, or process disclosed, or represents that its use would not infringe privately owned rights. Reference herein to any specific commercial product, process, or service by trade name, trademark, manufacturer, or otherwise, does not necessarily constitute or imply its endorsement, recommendation, or favoring by the United States Government or any agency thereof or its contractors or subcontractors. The views and opinions of authors expressed herein do not necessarily state or reflect those of the United States Government or any agency thereof. 
Prepared by:
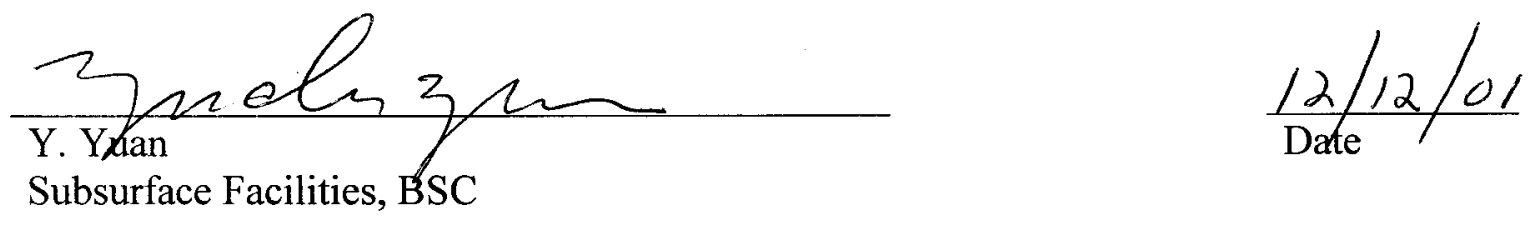

Checked by:
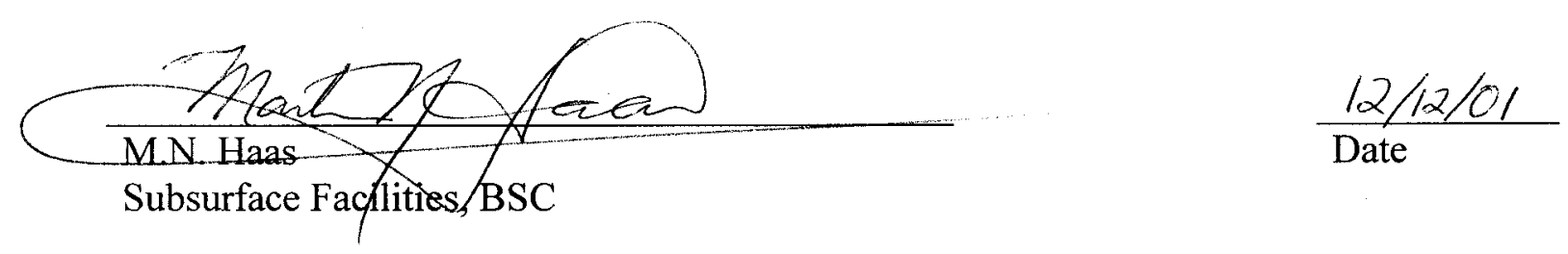

Approved by:

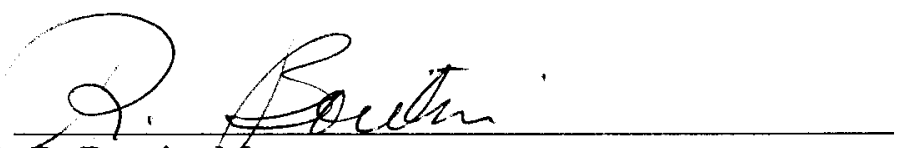

R. Boutin, Aanager

Subsurface Facilities, BSC

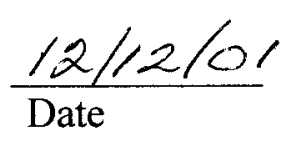




\section{CHANGE HISTORY}

$\begin{array}{ccll}\begin{array}{l}\text { Revision } \\ \text { Number }\end{array} & \begin{array}{l}\text { Interim } \\ \text { Change No. }\end{array} & \begin{array}{l}\text { Effective } \\ \text { Date }\end{array} & \text { Description of Change } \\ 00 & 00 & 11 / 16 / 01 & \text { Initial issue. } \\ 00 & 01 & \begin{array}{c}\text { - } 2 / 3<\gamma / 2 / 21 / 01 \\ 0 / 07 / 02\end{array} & \text { A unit typo has been corrected on p. } 24 .\end{array}$


INTENTIONALLY LEFT BLANK 


\section{CONTENTS}

Page

ACRONYMS AND ABBREVIATIONS

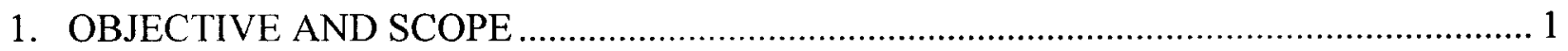

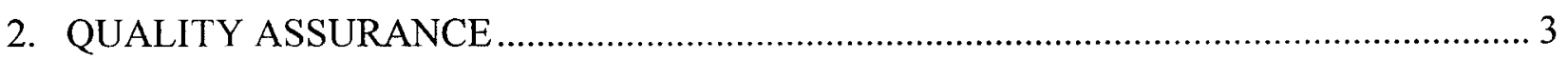

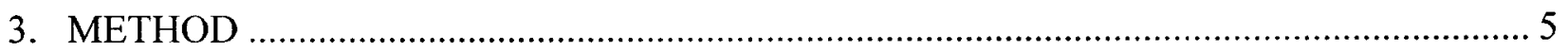

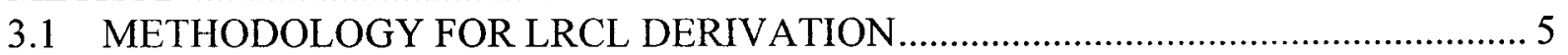

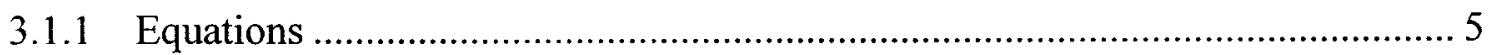

3.1.2 ALARA Requirements ............................................................................. 7

3.2 METHODOLOGY FOR RELEASE ESTIMATE AND ITS DETECTABILITY ..........8

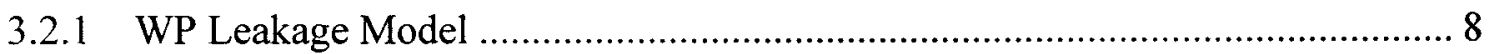

3.2.2 Release Detectability ............................................................................... 9

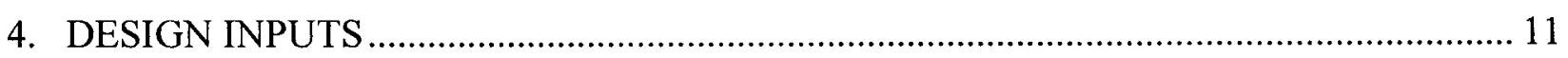

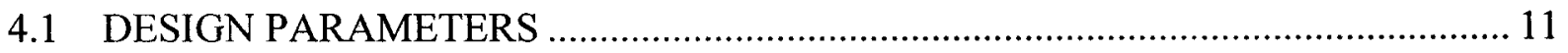

4.1.1 Emplacement Drift Ventilation Parameters ....................................................... 11

4.1.2 WP Design Parameters for Release Estimates................................................... 11

4.1.3 Radiological Parameters .......................................................................... 11

4.1.4 Gas Properties ........................................................................................ 12

4.1.5 Minimum Levels of Detectability …………….............................................. 13

4.1.6 Constants and Conversion Factors............................................................... 13

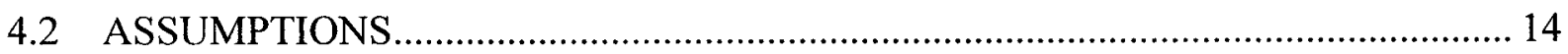

4.2.1 Pathway of Exposure ............................................................................. 14

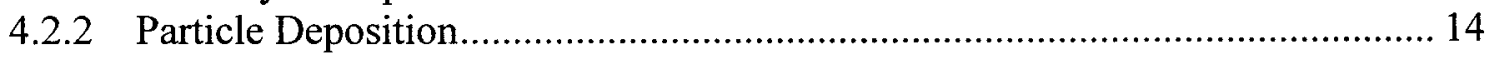

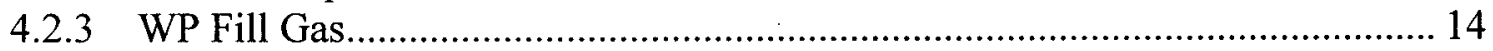

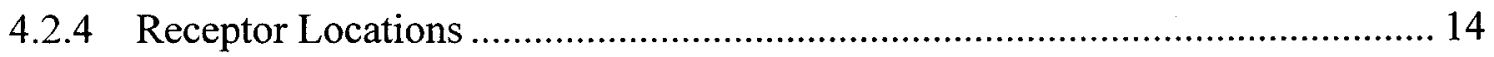

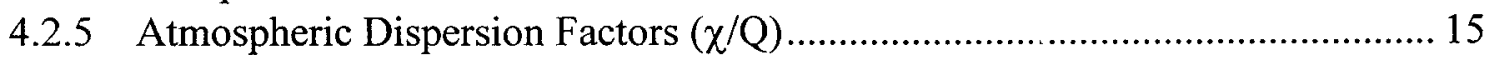

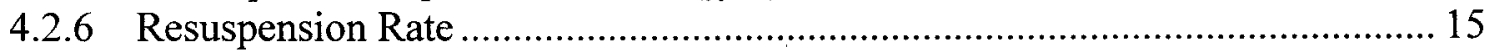

4.2.7 Respirable Fraction .................................................................................... 15

4.2.8 Repository Worker Work Hours ...................................................................... 15

4.2.9 Average Number of Workers during Emplacement Phase .............................. 15

4.2.10 WP Surface Area .................................................................................. 16

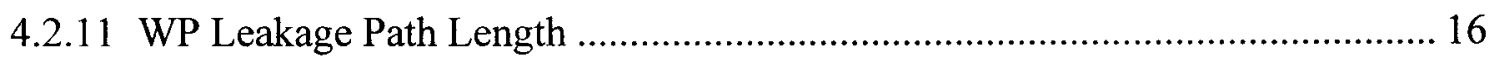

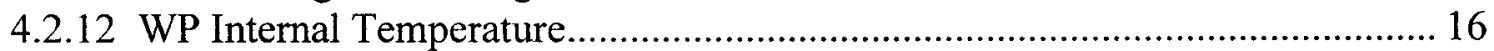

4.2.13 Average Annual WP Emplacement Rate......................................................... 16

4.2.14 Access Main Ventilation Rate ................................................................... 16

4.2.15 Shaft Exhaust Ventilation Rate ................................................................... 17

4.2.16 Release Evaluation Source Terms ……………........................................... 17

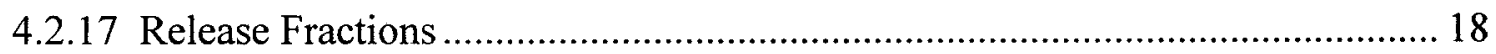

4.2.18 Leakpath Factor ..................................................................................... 19

4.2.19 Radioactive Decay from WP Surface Contamination ....................................... 19 


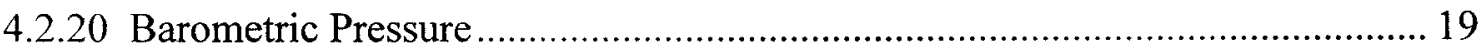

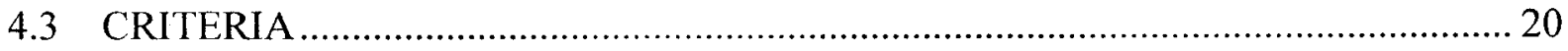

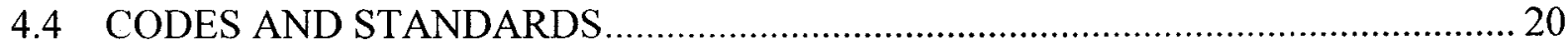

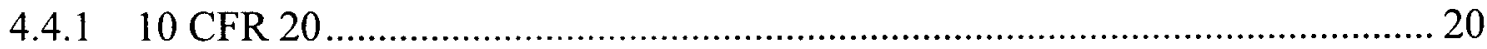

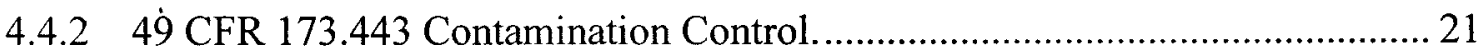

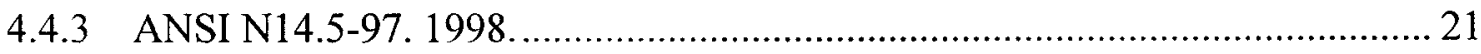

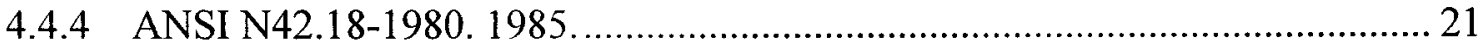

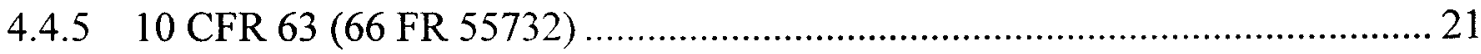

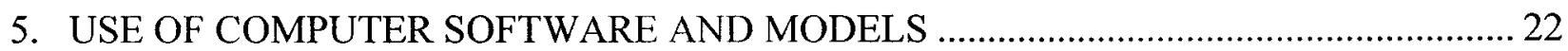

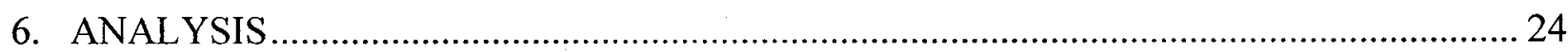

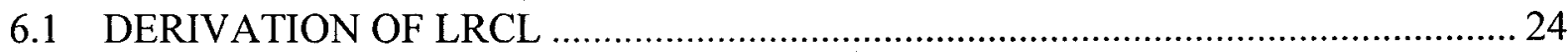

6.1.1 Single-Radionuclide LRCL ............................................................... 24

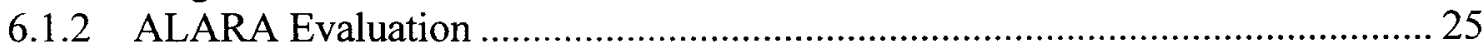

6.1.2.1 Offsite Maximum Individual Dose................................................ 25

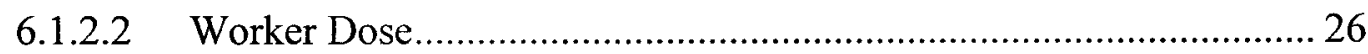

6.1.2.3 Total Collective Worker Dose.......................................................... 27

6.2 WP RELEASE AND ITS DETECTABILITY ........................................................... 28

6.2.1 Example 1: Leak-tight Hole Diameter................................................... 28

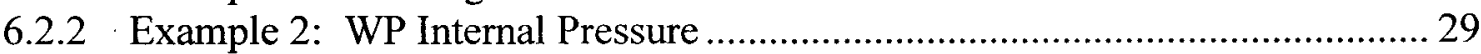

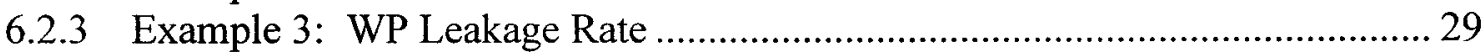

6.2.4 Example 4: Radionuclide Concentration and Detectability............................. 31

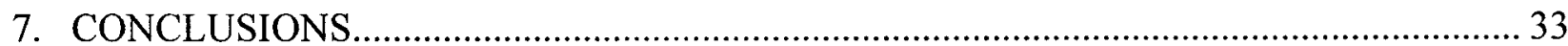

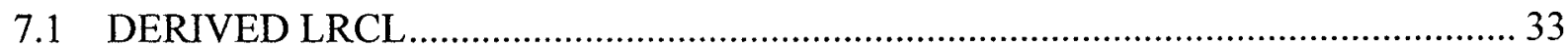

7.2 POTENTIAL WP LEAK AND ITS DETECTABILITY ........................................... 33

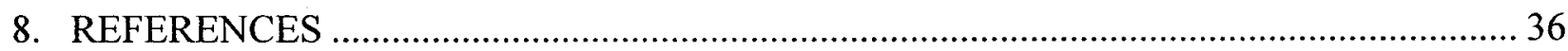

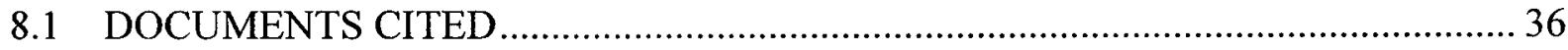

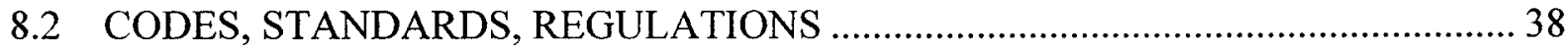

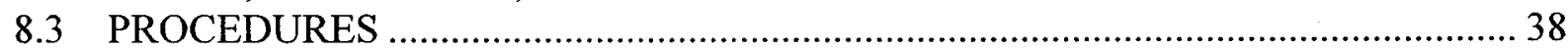

APPENDIX A - CALCULATION OF AVERAGE 21-PWR SOURCE TERMS ..................... A-1

APPENDIX B - DETERMINATION OF WP LEAK-TIGHT HOLE DIAMETER................... B-1

APPENDIX C - CALCULATION OF WP INTERNAL PRESSURE .................................... C-1

APPENDIX D - CALCULATION OF 21-PWR WP LEAKAGE RATE ................................ D-1

APPENDIX E - CALCULATION OF RADIONUCLIDE CONCENTRATIONS IN RAISE..E-1 


\section{FIGURES}

1. WP Leakage Rate as a Function of Hole size and Temperature 30

\section{TABLES}

\section{Page}

1. Airborne Effluent Limits and Derived Air Concentrations .................................................12

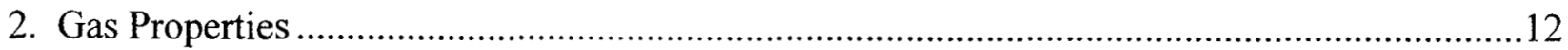

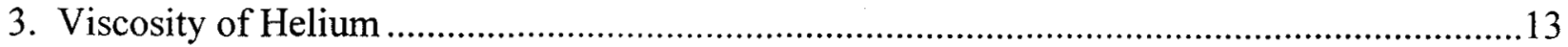

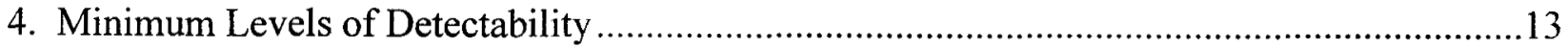

5. Radionuclide Source Terms for Release Evaluation ...........................................................18

6. SourceTerm Release Fractions by Radionuclide Group ..................................................19

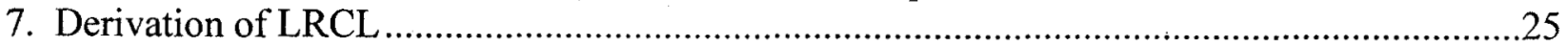

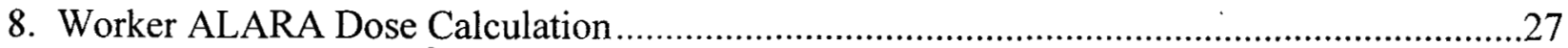

9. Air Leakage Rates $\left(\mathrm{cm}^{3} / \mathrm{s}\right)$ under Reference Conditions ..................................................28

10. WP Internal Pressure $(\mathrm{Pa})$ as a Function of Temperature and \% Fuel Rupture.......................29

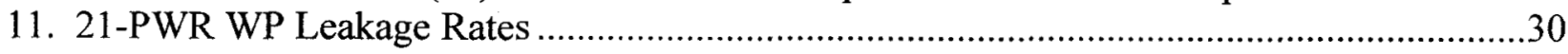

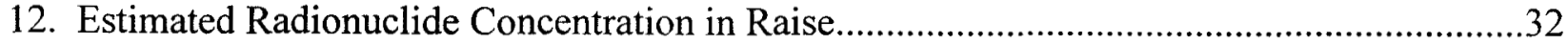


INTENTIONALLY LEFT BLANK 


\section{ACRONYMS AND ABBREVIATIONS}

$\begin{array}{ll}\text { ALARA } & \text { As Low As is Reasonably Achievable } \\ \text { ANSI } & \text { American National Standards Institute } \\ \text { AP } & \text { Administrative Procedure } \\ \text { BSC } & \text { Bechtel SAIC Company, LLC } \\ \text { CEDE } & \text { committed effective dose equivalent } \\ \text { LRCL } & \text { Limiting Radioactive Contamination Levels } \\ \text { CRWMS M\&O } & \begin{array}{l}\text { Civilian Radioactive Waste Management System Management and } \\ \text { Operations }\end{array} \\ \text { DAC } & \text { Derived Air Concentration } \\ \text { DOE } & \text { U.S. Department of Energy } \\ \text { ECL } & \text { effluent concentration limits } \\ \text { MGR } & \text { Monitored Geologic Repository } \\ \text { MLD } & \text { Minimum Level of Detectability } \\ \text { NRC } & \text { U.S. Nuclear Regulatory Commission } \\ \text { PWR } & \text { Pressurized Water Reactor } \\ \text { TBV, TBD } & \text { to-be-verified, to-be-determined } \\ \text { TEDE } & \text { total effective dose equivalent } \\ \text { WP } & \text { Waste Package }\end{array}$

\section{UNITS OF MEASURE}

$\begin{array}{ll}\text { Atm abs } & \text { Atmosphere absolute } \\ \mathrm{Bq} & \text { Becquerel } \\ \mathrm{Ci} & \text { Curie } \\ \mathrm{cm} & \text { centimeter } \\ { }^{\circ} \mathrm{C} & \text { degree Celsius (Centigrade) } \\ \mathrm{cP} & \text { centiPoise } \\ \mathrm{d} & \text { day } \\ \mathrm{dpm} & \text { disintegrations per minute }\end{array}$




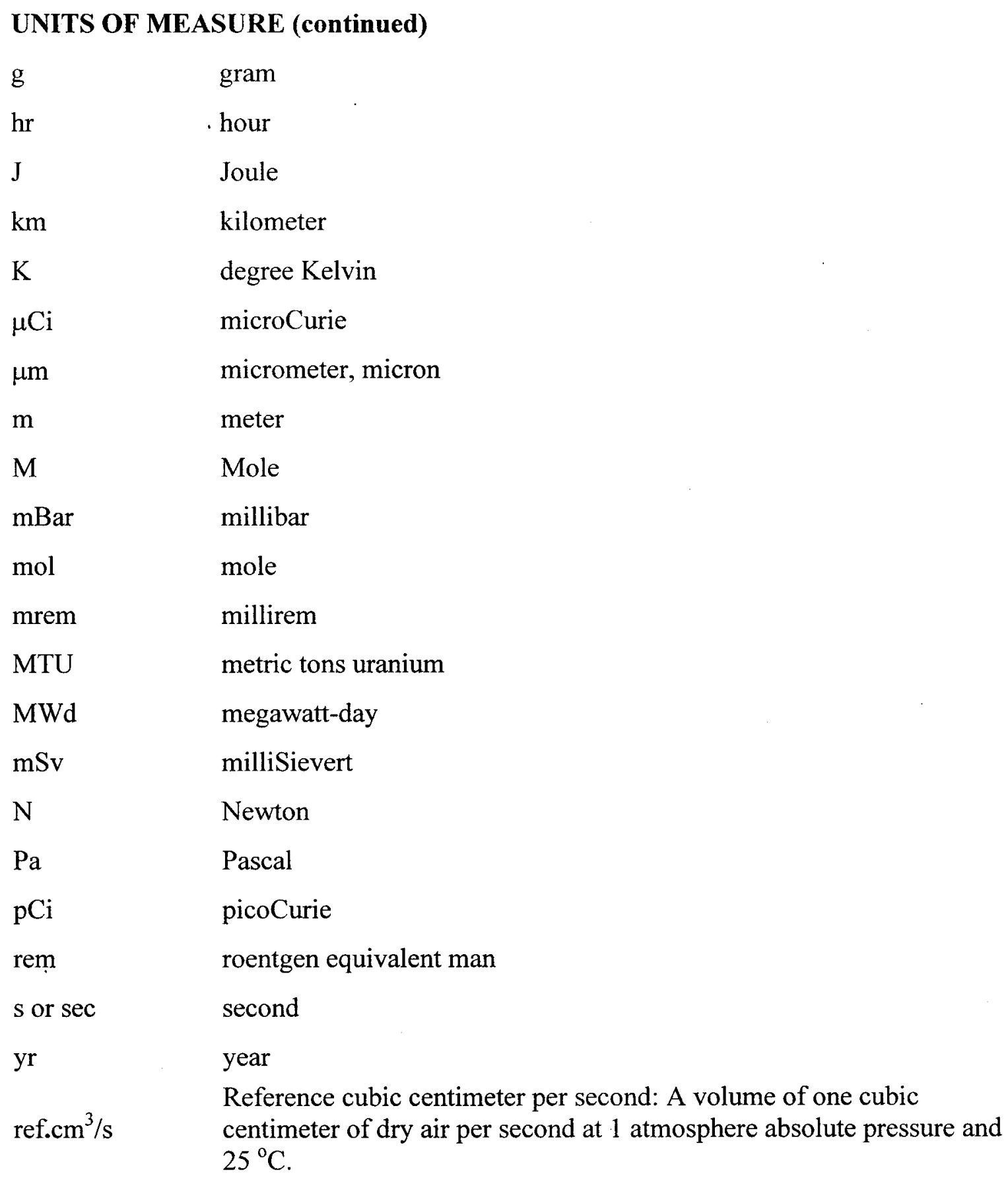


INTENTIONALLY LEFT BLANK 


\section{OBJECTIVE AND SCOPE}

There are two objectives of this report, "Subsurface Contamination Control". The first is to provide a technical basis for recommending limiting radioactive contamination levels (LRCL) on the external surfaces of waste packages (WP) for acceptance into the subsurface repository. The second is to provide an evaluation of the magnitude of potential releases from a defective WP and the detectability of the released contents.

The technical basis for deriving LRCL has been established in Retrieval Equipment and Strategy for WP on Pallet (CRWMS M\&O 2000g, 6.3.1). This report updates the derivation by incorporating the latest design information of the subsurface repository for site recommendation (see Subsections 4.2.14 and 4.2.15). The derived LRCL on the external surface of WPs, therefore, supercede that described in CRWMS M\&O 2000g. The derived LRCL represent the average concentrations of contamination on the external surfaces of each WP that must not be exceeded before the WP is to be transported to the subsurface facility for emplacement.

The evaluation of potential releases is necessary to control the potential contamination of the subsurface repository and to detect prematurely failed WPs. The detection of failed WPs is required in order to provide reasonable assurance that the integrity of each WP is intact prior to MGR closure. An emplaced WP may become breached due to manufacturing defects or improper weld combined with failure to detect the defect, by corrosion, or by mechanical penetration due to accidents or rockfall conditions. The breached WP may release its gaseous and volatile radionuclide content to the subsurface environment and result in contaminating the subsurface facility. The scope of this analysis is limited to radioactive contaminants resulting from breached WPs during the preclosure period of the subsurface repository.

This report:

- Documents a method for deriving LRCL on the external surfaces of WP for acceptance into the subsurface repository.

- Provides a table of derived LRCL for nuclides of radiological importance.

- Provides an as low as is reasonably achievable (ALARA) evaluation of the derived LRCL by comparing potential onsite and offsite doses to documented ALARA requirements.

- Provides a method for estimating potential releases from a defective WP.

- Provides an evaluation of potential radioactive releases from a defective WP that may become airborne and result in contamination of the subsurface facility.

- Provides a preliminary analysis of the detectability of a potential WP leak to support the design of an airborne release monitoring system. 
INTENTIONALLY LEFT BLANK 


\section{QUALITY ASSURANCE}

The development of this report was conducted under the Technical Work Plan for Subsurface Design Section FY01 Work Activities (CRWMS M\&O 2001); which was prepared in accordance with procedure AP-2.21Q, Quality Determinations and Planning for Scientific, Engineering, and Regulatory Compliance Activities. Specifically, it follows the work activities described in Subsurface Facility Lower Temperature Pre-closure Safety Support Work Package Number 12112124ML of the work plan in Technical Work Plan for Subsurface Design Section FY 01 Work Activities (CRWMS M\&O 2001, p. 15). This activity has been evaluated in accordance with AP-SV.1Q Control of the Electronic Management of Information. The activity evaluation of this work package (CRWMS M\&O 2001, pp. A-20 to A-21) has determined that the activities addressed in this report are subject to the requirements of the Quality Assurance Requirements and Description (DOE 2000, p. 2.2), since the radiological concerns addressed in this report generate data to be used to assess the potential dispersion of radioactive materials (CRWMS M\&O 2001, p. A-21). This report is written in accordance with AP-3.11Q, Technical Reports.

The implementation of the recommended LRCL on the external surfaces of WPs concerns MGR radiological control/safety (AP-3.11Q, p. 11) as well as subsurface worker health and safety. Therefore, this report is subject to technical baseline change in accordance with items $5.2 \mathrm{~d}$ 2) and 3) of AP-3.11Q. A Baseline Change Proposal (T2001-0153) has been prepared in accordance with AP-3.4Q, Level 3 Change Control. 
INTENTIONALLY LEFT BLANK 


\section{METHOD}

The methodologies used in the development of this report are detailed in the following Subsections. Subsection 3.1 presents the methodology used to derive the LRCL on the external surfaces of WPs for acceptance into the subsurface facility for emplacement. Subsection 3.2 presents the methodology used to evaluate the magnitude of potential releases from a breached WP and the detectability of the released contents.

\subsection{METHODOLOGY FOR LRCL DERIVATION}

The derivation of the LRCL on the external surface of waste packages is similar to that described in Retrieval Equipment and Strategy for WP on Pallet (CRWMS M\&O 2000g, 6.3.1). Final Rule 10 CFR Part 63.111(a)(1) (66 FR 55732) requires that the geologic repository operations area to meet the requirements stated in Title 10 of the Code of Federal Regulations (CFR) part 20. 10 CFR 20.1101(d) requires a licensee to implement the ALARA requirements such that the individual member of the public likely to receive the highest dose will not be expected to receive a total effective dose equivalent (TEDE) in excess of $10 \mathrm{mrem}(0.1 \mathrm{mSv})$ per yr from the air emissions. To estimate the highest dose to the individual member of the public, the release locations and the quantity of release from all MGR facilities are required. Since the total number of release points and their locations have not been determined, a conservative screening technique outlined in Regulatory Guide 4.20 Constraint on Releases of Airborne Radioactive Materials to the Environment for Licensees Other Than Power Reactors (1996) is used in this report to derive the LRCL. This screening technique, which is acceptable by NRC for demonstrating compliance with 10 CFR 20.1101(d), conservatively assumes that the air concentration at the boundary receptor is equal to the air concentration calculated at the point of release (Regulatory Guide 4.20 1996, Subsection 2.1). This is analogous to demonstrating that the annual average concentrations of radioactive material released in gaseous effluents at the location of the exhaust do not exceed the values specified in Table 2 of Appendix B to 10 CFR Part 20 which are the airborne effluent concentration limits (ECL). 10 CFR 20.1302(b)(2)(i) requires that the annual average concentrations of radioactive material released in gaseous effluents at the boundary of the unrestricted area do not exceed the ECL values (see Subsection 4.4.1).

\subsubsection{Equations}

The airborne release at the shaft exhaust due to contamination on WP surfaces may be derived based on the following parameters:

- A: The surface area of the average WP, $\left(\mathrm{m}^{2}\right)$

- $\mathrm{N}$ : The average number of WPs emplaced per year, $(1 / \mathrm{yr})$

- $\mathrm{C}_{\mathrm{s}}$ : The initial contamination levels on the surface of WP, $\left(\mathrm{dpm} / 100 \mathrm{~cm}^{2}\right.$ or $\left.\mathrm{Ci} / \mathrm{m}^{2}\right)$

The mass balance equation for WP surface contamination in the repository with respect to time resulting from emplacement operation is: 


$$
\frac{\mathrm{dC}_{\mathrm{R}}}{\mathrm{dt}}=\mathrm{NC}_{\mathrm{s}} \mathrm{A}-\mathrm{kC}_{\mathrm{R}}
$$

where:

$\mathrm{C}_{\mathrm{R}}=$ time dependent surface contamination on the WPS

$\mathrm{k}=\lambda+\omega$

$\lambda=$ radioactive decay constant $(1 / \mathrm{yr})$

$\omega=$ re-suspension rate of the surface contamination $(1 / \mathrm{yr})$

The solution for equation (1) at time $t$ following the start of emplacement operation is:

$$
\mathrm{C}_{\mathrm{R}}=\frac{\mathrm{NC}_{\mathrm{s}} \mathrm{A}}{\mathrm{k}}\left(1-\mathrm{e}^{-\mathrm{kt}}\right)
$$

Because the WP inventory in the repository builds up during emplacement operations, the WP surface contamination and the potential re-suspended release at the final year of operation will be at a maximum level. If $\mathrm{T}$ represents the last operation year, the potential re-suspended release per year during the final year of operation is:

$$
\mathrm{R}=\mathrm{N} \mathrm{C} \mathrm{s} \frac{\omega}{\mathrm{k}}\left(1-\mathrm{e}^{-\mathrm{kT}}\right)
$$

Based on the above equation the maximum value of $R$ occurs when $T$ approaches a very large number and if radioactive decay is negligible (Subsection 4.2.19) or:

$$
\mathrm{R}=\mathrm{N} \mathrm{C}_{\mathrm{s}} \mathrm{A}
$$

The average annual concentration at a receptor location, $\mathrm{C}_{\mathrm{a}}\left(\mathrm{Ci} / \mathrm{m}^{3}\right)$, conservatively assuming little or no deposition of released material from the WPs to the exhaust shaft (Assumption 4.2.2), may be calculated as:

$$
\mathrm{C}_{\mathrm{a}}=3.17 \times 10^{-8} \sum_{\mathrm{i}}^{\mathrm{M}} \mathrm{R}_{\mathrm{i}}(\chi / \mathrm{Q})_{\mathrm{i}}
$$

where: $\mathrm{M}$ = total number of release points

$(\chi / Q)_{i}=$ atmospheric dispersion factor at a receptor from release point $\mathrm{i},\left(\mathrm{s} / \mathrm{m}^{3}\right)$

$\mathrm{R}_{\mathrm{i}} \quad=$ release from point $\mathrm{i}$

$\mathrm{i} \quad=$ release point index

$3.17 \times 10^{-8}=$ conversion from second to year $(\mathrm{s} / \mathrm{yr})$

$$
=1 /[365(\mathrm{~d} / \mathrm{yr}) \times 24(\mathrm{hr} / \mathrm{d}) \times 3600(\mathrm{~s} / \mathrm{hr})]
$$

Eq.5 may be used to derive LRCL if $\mathrm{R}_{\mathrm{i}}$ and $(\chi / \mathrm{Q})_{\mathrm{i}}$ are known.

As described in Subsection 3.1, since the total number of release points and their locations have not been determined, a conservative screening technique provided by NRC in Regulatory Guide 4.20 (1996) is used to derive the LRCL. This screening technique conservatively assumes that 
the air concentration at the site boundary receptor is equal to the air concentration calculated at the location of the exhaust. This is analogous to demonstrating that the annual average concentrations of radioactive material released in gaseous effluents at the location of the exhaust do not exceed the values of ECL.

At the ventilation exhaust shaft, the average annual concentration is:

$$
\mathrm{C}_{\mathrm{a}}=\mathrm{R} / \mathrm{V}=\left(\mathrm{N} \mathrm{C}_{\mathrm{s}} \mathrm{A}\right) / \mathrm{V}
$$

where $\mathrm{V}$ is the ventilation flow rate in $\mathrm{m}^{3} / \mathrm{yr}$ of the ventilation shaft exhaust and $\mathrm{C}_{\mathrm{s}}$ represents the LRCL for all WPs.

Setting the exhaust concentration, $\mathrm{C}_{\mathrm{a}}$, to the effluent concentration limit, $\mathrm{ECL}$, and solving for the $\mathrm{LRCL}$ or $\mathrm{C}_{s}$, yields the following:

$$
\mathrm{C}_{\mathrm{s}}=(\mathrm{ECL} \times \mathrm{V}) /(\mathrm{A} \times \mathrm{N})
$$

Equation (7) is derived for calculating a single-radionuclide LRCL. The approach used in deriving Eq. 7 is very conservative because the LRCL are applied equally to all WPs.

When applying the derived single-radionuclide LRCL for survey of a decontaminated WP, the sum-of-fractions rule may be applied (Regulatory Guide 4.201996 , Subsection 2.2). That is, the summation of the fractional LRCL of radionuclides remaining on a WP should not be greater than unity, or

$$
\sum_{i} \frac{C_{i}}{C_{s, i}} \leq 1
$$

where $C_{i}$ is the average concentration of the ith nuclide on the surface of the WP and $C_{s, i}$ is the single-radionuclide LRCL derived for the ith nuclide.

The calculation of $\mathrm{C}_{\mathrm{s}, \mathrm{i}}$ for radionuclides of radiological importance is made in Subsection 6.1.

\subsubsection{ALARA Requirements}

The ALARA requirements applicable to the derived LRCL are those outlined in the Monitored Geologic Repository Project Description Document (Curry, P.M. 2001, Subsections 5.3.3, 5.3.4 and 5.3.5). The specific requirements are presented in Subsection 4.3.

The applicable codes and standards and ALARA dose requirements stated by NRC are presented in Subsection 4.4.

To demonstrate that the derived LRCL will be ALARA, the annual offsite and onsite individual doses are estimated in Subsection 6.1.2 and compared with the applicable dose requirements (see Subsections 4.3 and 4.4.1). Dose estimates are made assuming that the average contamination level on the external surfaces of each WP is at the derived LRCL. 


\subsection{METHODOLOGY FOR RELEASE ESTIMATE AND ITS DETECTABILITY}

This Section presents the methodology used to estimate the amount of radioactive material that may be released from a breached WP and its detectability during the preclosure period. The methodology for estimating release is based primarily on the container leakage model described in American National Standard for Radioactive Materials - Leakage Tests on Packages for Shipment (ANSI N14.5-97. 1998, Annex B). The model is presented in Subsection 3.2.1. The method used to evaluate release detectability is presented in Subsection 3.2.2 and is based on the ventilation design of the subsurface facility and the minimum levels of detectability (MLD) for radionuclides in gaseous effluent streams as specified by ANSI N42.18-1980 (1985, Table 1).

It should be recognized that the radioactive contents of a WP would be released into the environment only if they are first released to the WP interior voids and subsequently escaped from the voids to the external environment. This would require a breach of the WP outer barrier, inner shell and waste form container. Gas leakage through a small leak depends on properties of the gas and the characteristics of the leakage path. Pressure difference is the driving force for a WP leak. Release of suspended particles from the WPs is caused by particle entrainment in the escaping gas.

\subsubsection{WP Leakage Model}

This Subsection summarizes the leakage model provided by the ANSI (ANSI N14.5-97 1998, Annex B). The model is used in this report for estimating the leakage rate $\mathrm{L}\left(\mathrm{cm}^{3} / \mathrm{sec}\right)$ from a breached WP, or the pathway through the WP cavity to the external environment.

The equations described in ANSI N14.5-1997 (1998, pages 27-28) are modeled based on a straight circular tube leakage path and represent flow that is in the free molecular and/or continuum flow regimes.

The equations used by ANSI N14.5-1997 to estimate volume leakage rate from a container (or in this report, a WP) of releasable material inside the WP void are:

$$
\begin{gathered}
L=\left(F_{c}+F_{m}\right)\left(P_{u}-P_{d}\right) P_{a} / P_{u} \\
F_{c}=\frac{2.49 \times 10^{6} D^{4}}{\alpha \mu} \\
F_{m}=\frac{3.81 \times 10^{3} D^{3} \sqrt{T / M}}{\alpha P_{a}}
\end{gathered}
$$

where

$$
\begin{aligned}
& \alpha=\text { leakage hole length, } \mathrm{cm} \\
& \mu=\text { viscosity of the leaking gas, } \mathrm{cP} \\
& \mathrm{D}=\text { leakage hole diameter, cm } \\
& \mathrm{T}=\text { fluid absolute temperature }, \mathrm{K}
\end{aligned}
$$


$\mathrm{M}=$ molecular weight, grams per mole

$\mathrm{P}_{\mathrm{a}}=$ average stream pressure $=0.5\left(\mathrm{P}_{\mathrm{u}}+\mathrm{P}_{\mathrm{d}}\right)$, atm abs

$\mathrm{P}_{\mathrm{u}}=$ fluid upstream pressure, atm abs

$P_{d}=$ fluid downstream pressure, atm abs

$\mathrm{L}=$ volumetric leakage rate, $\mathrm{cm}^{3} / \mathrm{s}$

$\mathrm{F}_{\mathrm{c}}=$ coefficient of continuum flow conductance per unit pressure, $\mathrm{cm}^{3} / \mathrm{atm}-\mathrm{s}$

$\mathrm{F}_{\mathrm{m}}=$ coefficient of free molecular flow conductance per unit pressure, $\mathrm{cm}^{3} / \mathrm{atm}-\mathrm{s}$

\subsubsection{Release Detectability}

The method used in this report to evaluate detectability of released material is based on the ventilation design of the subsurface facility and the MLD for radionuclides in gaseous effluent streams as specified by ANSI N42.18-1980 (1985, Table 1). The MLDs specified by the ANSI N42.18-1980 are applicable for instruments designed to continuously monitor radioactivity in gaseous effluent streams. The sensitivity of using air samples to detect potential leaks is evaluated by comparing the released concentrations to the MLD for radionuclides in gaseous effluent streams. The radionuclide concentrations in the effluent streams are estimated based on the gaseous leakage rates, the WP radioactive contents, the release fractions, and the subsurface ventilation flow rates. The input parameters used in this report for evaluating release detectability are included in Subsection 4. 
INTENTIONALLY LEFT BLANK 


\section{DESIGN INPUTS}

All technical product input and sources of the input used in the development of this report are documented in this section. The qualification status of the input is indicated in the Document Input Reference System database in accordance with AP-3.15Q, Rev 3, ICN 0, Managing Technical Product Inputs.

\subsection{DESIGN PARAMETERS}

The design parameters used in this report are identified and provided in the following Subsections. All of the following parameters are used either in Section 6 or the Appendices.

\subsubsection{Emplacement Drift Ventilation Parameters}

The emplacement drift and raise ventilation airflow rates are taken from Site Recommendation Subsurface Layout (BSC 2001b) and are provided as follows:

- Emplacement Drift airflow rate: $15 \mathrm{~m}^{3} / \mathrm{s}$ (BSC 2001b, Subsection 6.2.4.2)

- Emplacement Raise airflow rate: $2 \times 15 \mathrm{~m}^{3} / \mathrm{s}=30 \mathrm{~m}^{3} / \mathrm{s}$ (BSC 2001b, Subsection 6.2.4.2)

\subsubsection{WP Design Parameters for Release Estimates}

The 21-Pressurized Water Reactor (PWR) WP is used in Subsection 6.2 as a representative WP configuration for estimating source terms and potential releases. This WP configuration is appropriate because it represents the largest projected quantity of WP inventory (Curry, P.M. 2001, p. 5-9 and p. 5-10) to be placed in the repository. The design parameters associated with the 21-PWR WP configuration are provided as follows:

- Number of fuel rod per assembly: 208 (CRWMS M\&O 2000f, p. III-3)

- Number of assembly per WP: 21 (CRWMS M\&O 2000f, p. III-3)

- WP void volume: $4.38 \mathrm{~m}^{3}$ (CRWMS M\&O 2000f, p. III-3)

- PWR fuel rod void volume: $35 \mathrm{~cm}^{3}$ (CRWMS M\&O 2000f, p. III-3)

- Initial helium gas moles in WP void: 179.1 (CRWMS M\&O 2000f, p. III-3)

- Initial helium gas moles in fuel rod void: 0.117 (CRWMS M\&O 2000f, p. III-3).

\subsubsection{Radiological Parameters}

The LRCL are derived only for those radionuclides that were found to contribute collectively to more than $99 \%$ of the total effective dose equivalent from inhalation following a nonmechanistic design basis event. The specific calculation used to obtain the radionuclide lists is described in page 26 of the Software Qualification Report for RSAC-5 Version 5.2 the Radiological Safety Analysis Computer Program (CRWMS M\&O 1998, p. 26). Table 1 lists the individual radionuclides selected, their airborne ECL (Column 1 of Table 2 of Appendix B to 10 CFR 20) and their derived air concentrations (DAC) (Column 3 of Table 1 of Appendix B to 10 CFR 20). Cs-137 is included because it has relatively high inventory in the spent nuclear 
fuel. Gaseous radionuclides such as tritium and $\mathrm{Kr}-85$ are excluded from the table because they would not be present as surface contamination on a WP. The airborne ECL represents the concentration, which if inhaled continuously over the course of a year, would produce a TEDE of 50 mrem (10 CFR 20, Appendix B). The ECL values are used in Subsection 6.1 to derive the LRCL. The DAC values are used in Subsections 6.1.2.2 and 6.1.2.3 to calculate repository worker doses.

Table 1. Airborne Effluent Limits and Derived Air Concentrations

\begin{tabular}{|c|c|c|}
\hline & $\mathrm{ECL}^{\mathrm{a}}$ & $\mathrm{DAC}^{\mathrm{b}}$ \\
\hline Radionuclide & $\mathrm{Ci}^{3}$ & $\mathrm{Ci} / \mathrm{m}^{3}$ \\
\hline Co-60 & $5 \times 10^{-11}$ & $1 \times 10^{-8}$ \\
Sr-90 & $6 \times 10^{-12}$ & $2 \times 10^{-9}$ \\
Cs-137 & $2 \times 10^{-10}$ & $6 \times 10^{-8}$ \\
Pu-238 & $2 \times 10^{-14}$ & $3 \times 10^{-12}$ \\
Pu-239 & $2 \times 10^{-14}$ & $3 \times 10^{-12}$ \\
Pu-240 & $2 \times 10^{-14}$ & $3 \times 10^{-12}$ \\
Pu-241 & $8 \times 10^{-13}$ & $1 \times 10^{-10}$ \\
Am-241 & $2 \times 10^{-14}$ & $3 \times 10^{-12}$ \\
Cm-244 & $3 \times 10^{-14}$ & $5 \times 10^{-12}$ \\
\hline
\end{tabular}

NOTES: ${ }^{a}$ Source: 10 CFR 20 Appendix B, Column 1 of Table 2. This column lists the "radionuclide concentrations which, if inhaled ... continuously over the course of a year, would produce a total effective dose equivalent (TEDE) of 50 mrem." For conservatism, the lowest or most restrictive listed values are used in this report.

${ }^{b}$ Source: 10 CFR 20 Appendix B, Column 3 of Table 1. For conservatism, the lowest or most restrictive listed values are used in this report.

\subsubsection{Gas Properties}

The values of molecular weight (M) and viscosity $(\mu)$ for air and helium (at $298 \mathrm{~K}$ and 1 atm abs.) provided in ANSI N14.5-1997 (1998, p. 28) are reproduced in Table 2:

Table 2. Gas Properties

\begin{tabular}{|c|c|c|}
\hline Gas Name & M (g-mol) & $\mu$ (cP) \\
\hline Air & 29 & 0.0185 \\
\hline Helium & 4.0 & 0.0198 \\
\hline \multicolumn{2}{|l}{ Source: ANSI N14.5-1997 (1998, p. 28) }
\end{tabular}


The viscosity of gas at low-density range is dependent on temperature and not on pressure (Bird et al. 1960, p. 24). The viscosity $(\mu)$ of helium at 300,350 and $500{ }^{\circ} \mathrm{C}$ calculated using the chart provided in Perry et al. (1984, p. 3-248) are provided in Table 3:

Table 3. Viscosity of Helium

\begin{tabular}{|c|c|}
\hline Temperature $\left({ }^{\circ} \mathrm{C}\right)$ & Viscosity (cP) \\
\hline 300 & 0.030 \\
\hline 350 & 0.032 \\
\hline 500 & 0.038 \\
\hline
\end{tabular}

\subsubsection{Minimum Levels of Detectability}

The values of minimum level of detectability (MLD) in gaseous effluent streams provided by ANSI N42.18-1980 (1985, Table 1) are presented in Table 4. These MLDs are applicable for instruments designed to continuously monitor radioactivity in gaseous effluent streams.

Table 4. Minimum Levels of Detectability

\begin{tabular}{|c|c|}
\hline Radionuclide & $\mathrm{MLD}^{\mathrm{a}}\left(\mu \mathrm{Ci} / \mathrm{cm}^{3}\right)$ \\
\hline Co-60 & $8 \times 10^{-11}$ \\
\hline $\mathrm{Kr}-85$ & $3 \times 10^{-7}$ \\
\hline Sr-90 & $4 \times 10^{-12}$ \\
\hline Cs-137 & $5 \times 10^{-12}$ \\
\hline Pu-238 & $2 \times 10^{-12}$ \\
\hline Pu-239 & $2 \times 10^{-12}$ \\
\hline
\end{tabular}

NOTES: ${ }^{a}$ Source: ANSI N42.18-1980 (1985, Table1)

\subsubsection{Constants and Conversion Factors}

The following constants and conversion factors are used in this report:

Gas-law Constant: $8.3144 \mathrm{~J} \mathrm{~mol}^{-1} \mathrm{k}^{-1}$ (Source: Perry et al. 1984, p. 1-18)

1 Atmosphere $(\mathrm{atm})=101,325 \mathrm{~Pa}\left(\right.$ or N$/ \mathrm{m}^{2}$ ) (Source: Perry et al. 1984, p. 1-15)

$1 \mathrm{Bar}=0.9869$ Atmosphere (atm) (Source: Perry et al. 1984, p. 1-15) 


\subsection{ASSUMPTIONS}

All of the following assumptions are used either in Subsection 6.1 for the derivation of LRCL, or in Subsection 6.2, and the Appendices for the estimation of WP leakage rates and concentrations.

\subsubsection{Pathway of Exposure}

For ALARA offsite dose calculations, only inhalation doses are considered. The potential doses from external radiation exposure, ingestion, air and water immersion, and contaminated soil are not considered significant and are based on the dose calculation results of Design Basis Event Frequency and Dose Calculation for Site Recommendation (CRWMS M\&O 2000b, p. 45) which states that the majority (more than 77\%) of the total dose from Category 1 events is derived from the inhalation pathway.

This assumption is appropriate because the calculated dose is so low (see Subsection 6.1.2) that a rough estimate is sufficient to support the conclusions of the ALARA evaluations. This assumption is used in Subsection 6.1.

\subsubsection{Particle Deposition}

In airborne concentration calculations, no deposition is assumed. This assumption is appropriate because zero deposition is conservative in the absence of site-specific data. This assumption is used in Subsection 3.1.1. For potential deposition of suspended radioactive materials on the ground surface of the repository, it is assumed that the Radiation Protection Program of the repository will minimize the spreading of radioactive contamination between work areas and will maintain radiation exposures ALARA.

\subsubsection{WP Fill Gas}

Helium gas will be used to provide an inert atmosphere within the WP. This assumption is based on the current WP design requirement described in the Uncanistered Spent Nuclear Fuel Disposal Container System Description Document (BSC 2001c, Subsection 2.4.3) and is used in Section 6.2 for WP leakage calculations.

\subsubsection{Receptor Locations}

The maximum offsite public dose receptor is assumed to be at a distance of $8 \mathrm{~km}$ from the release point. The maximum onsite surface worker dose receptor is assumed to be at a distance of $100 \mathrm{~m}$ from the release point. These distances are conservative and are consistent with the distances used in the Design Basis Event Frequency and Dose Calculation for Site Recommendation (CRWMS M\&O 2000b, p. 14). The average onsite surface worker dose receptor is assumed to be at a distance of $3000 \mathrm{~m}$ from the release point. This distance represents the minimum distance from a subsurface exhaust shaft to the Waste Handling Building and is estimated from Figure I-19 of the Engineering Files for Site Recommendation (CRWMS M\&O 2000a, Figure I-19).

These assumed receptor locations are used in Subsection 6.1 for onsite worker and offsite public dose calculations. 


\subsubsection{Atmospheric Dispersion Factors $(\chi / Q)$}

The " $\chi / \mathrm{Q}$ " value of $3.19 \times 10^{-7}\left(\mathrm{~s} / \mathrm{m}^{3}\right)$ is conservatively based on the value at $7.5 \mathrm{~km}$ and is used in Subsection 6.1.2.1 to calculate the maximum offsite public dose at $8 \mathrm{~km}$ (Assumption 4.2.4). The " $\chi / \mathrm{Q}$ " values of $4.77 \times 10^{-4}\left(\mathrm{~s} / \mathrm{m}^{3}\right)$ and $1.23 \times 10^{-6}\left(\mathrm{~s} / \mathrm{m}^{3}\right)$, respectively, are used in Subsection 6.1.2.1 to calculate the maximum surface worker dose at $100 \mathrm{~m}$ and the average surface worker dose at $3 \mathrm{~km}$ (Assumption 4.2.4). These " $\chi / Q$ " values are taken from Calculations of Acute and Chronic "Chi/ $Q$ " Dispersion Estimates for a Surface Release (CRWMS M\&O 1999a, p. 23-24) and were calculated based on Yucca Mountain site-specific meteorological data. These factors are appropriate because they were calculated based on Yucca Mountain site-specific data and are the most conservative " $\chi / Q$ " values at the assumed receptor locations.

\subsubsection{Resuspension Rate}

It is assumed in the WP contamination resuspension calculations that the resuspension rate is $4 \times 10^{-5} / \mathrm{hr}$. This resuspension factor is the bounding value recommended for aerodynamic entrainment of powders from unyielding surfaces for indoors or outdoors exposed to ambient conditions following an event (DOE 1994a, p. 5-7). This assumption is used in worker dose calculations presented in Subsection 6.1.2.

\subsubsection{Respirable Fraction}

It is assumed in the dose calculations that all released or suspended radioactive particles are respirable. This assumption is used in Subsection 6.1.2 for dose calculations and is appropriate because it yields the most conservative dose values.

\subsubsection{Repository Worker Work Hours}

The repository worker is assumed to spend full time $(2,000 \mathrm{hr})$ at the repository site. This value is appropriate because it bounds the number of hours a typical worker will spend inside the repository. This assumption is used in Subsection 6.1.2.2 for worker dose calculations.

\subsubsection{Average Number of Workers during Emplacement Phase}

The average number of full time subsurface facility workers during the emplacement period is 90. This number is taken from the most recent conceptual design engineering file, FEIS Update to Engineering File - Subsurface Repository (CRWMS M\&O 2000d, p. 6-13). The average number of full time surface facility workers during the emplacement period is 1305 . This number is taken from Repository Surface Design Engineering Files Report Supplement (CRWMS M\&O 2000i, Table 6-2.). These input values are appropriate because they represent the latest design information available and a rough estimate is sufficient to support the conclusions of the ALARA collective worker dose evaluation. These average worker numbers are used in Subsection 6.1.2.3 for collective worker dose calculations. 


\subsubsection{WP Surface Area}

The WP surface area is assumed to be $32 \mathrm{~m}^{2}$. This area was determined by comparison of projected WP inventory and surface areas of all WP categories to be placed in the repository (CRWMS M\&O $2000 \mathrm{~g}$, p. 63). This surface area size is greater than $98 \%$ (CRWMS M\&O $2000 \mathrm{~g}$, Table 3 ) of the projected WP inventory; therefore, it is conservative to use this value to derive the LRCL in Subsection 6.1.1.

\subsubsection{WP Leakage Path Length}

The WP leakage path length is assumed to be $7 \mathrm{~cm}$. This length represents the combined length of the stainless steel inner cylinder thickness of $5 \mathrm{~cm}$ and an alloy 22 outer cylinder thickness of $2 \mathrm{~cm}$ (BSC 2001c, Criterion 1.2.1.4). This assumption is used in Subsection 6.2 and Appendix D for WP leakage rate calculations.

\subsubsection{WP Internal Temperature}

The WP internal temperatures are assumed to be 300,350 and $500{ }^{\circ} \mathrm{C}$ for WP potential release calculations. The internal temperatures of 300 and $350^{\circ} \mathrm{C}$ are used to calculate potential releases under normal conditions. The $500{ }^{\circ} \mathrm{C}$ is used to calculate releases from a hypothetical abnormal event: a short-term exposure to fire (BSC 2001c, Criterion 1.2.1.6). This assumption is used to provide a range of potential WP internal temperatures and pressures during the preclosure period and is consistent with the current WP temperature requirements (BSC 2001c, Criterion 1.2.1.6). These temperatures are appropriate because they demonstrate that a change in WP temperature would only produce a minor change in the calculated release and will not change the conclusions of the WP release analysis (see Subsection 6.2.3). This assumption is used in Subsection 6.2 and Appendices.

\subsubsection{Average Annual WP Emplacement Rate}

The average number of WPs emplaced annually is assumed to be 605 . This number is taken from the assumption made in Retrieval Equipment and Strategy for WP on Pallet (CRWMS M\&O 2000g, p. 21). It represents an upper bound estimate of the WP emplacement rate. This assumption is used in Subsection 6.1.

\subsubsection{Access Main Ventilation Rate}

The ventilation rate in the Access Main during normal operations is assumed to be $45.6 \mathrm{~m}^{3} / \mathrm{s}$.

This ventilation rate is calculated based on the $1 \mathrm{~m} / \mathrm{s}$ minimum airflow velocity for human access during normal operations assumed in Site Recommendation Subsurface Layout (BSC 2001b, Subsection 5.2.7.1). Using an Access Main diameter of $7.62 \mathrm{~m}$ (BSC 2001b, Subsection 6.3.2.1) the volumetric flow rate of: $1 \mathrm{~m} / \mathrm{s} \times 3.1416 \times 3.81^{2} \mathrm{~m}^{2}=45.6 \mathrm{~m}^{3} / \mathrm{s}$ is obtained. This assumption is used in Subsection 6.1.2.2.2 for subsurface worker dose calculations. This assumption is appropriate because it provides a conservative estimate for dilution of released material in the Access Main and therefore provides a conservative estimate of routine subsurface worker dose. 


\subsubsection{Shaft Exhaust Ventilation Rate}

The Shaft Exhaust ventilation rate is assumed to be $715 \mathrm{~m}^{3} / \mathrm{s}$. This ventilation rate is taken from Overall Ventilation System Flow Network Calculation for Site Recommendation (BSC 2001a, Subsection 5.1.4) and is used in Subsection 6.1 for deriving WP contamination limits. This assumption is appropriate because it represents the latest design of the repository for site recommendation.

\subsubsection{Release Evaluation Source Terms}

For WP release and detection evaluation, the average fuel source terms (fission gases, volatiles, and fuel particulates) are taken from PWR Source Term Generation and Evaluation (CRWMS M\&O 1999b, Attachment X). These source terms are derived based on PWR fuel with 4\% initial enrichment, $48 \mathrm{GWd} / \mathrm{MTU}$ burnup, and 25-year decay period (CRWMS M\&O 1999b, p. 24). The maximum expected crud concentration, represented by Co- 60 , is $140 \mu \mathrm{Ci} / \mathrm{cm}^{2}$ at the time of discharge (ANSI N14.5-97 1998, p. 46). Using a conservative surface area of a single fuel assembly of 449,003 $\mathrm{cm}^{2}$ (CRWMS M\&O 1999b, p. 25) and a decay half-life of $5.271 \mathrm{yr}$ taken from Radioactive Decay Data Tables, A Handbook of Decay Data for Application to Radiation Dosimetry and Radiological Assessments (Kocher, D.C. 1981, p. 78), the total quantity of crud (Co-60) is estimated to be $63 \mathrm{Ci}$ per assembly at the time of discharge and $2.35 \mathrm{Ci}$ at 25 years following discharge. The calculation of the radionuclide source terms in the average 21-PWR WP is provided in Appendix A. Table 5 lists the radionuclide source terms in the average PWR spent fuel assembly and the 21-PWR WP. The individual radionuclides listed in Table 5 are for release detection evaluations. The radionuclides selected are those radiologically important radionuclides listed in Table 1 and those also with specific minimum level of detectability (MLD) values provided by ANSI N42.18-1980 (1985, Table 1) (see Table 4). Kr-85 is included because it is an inert gas with relatively high inventory in the spent nuclear fuel. These isotopes are appropriate for evaluating WP release detectability since the source terms are representative of the fuel to be emplaced and the actual release would be dependent on the specific fuel which has failed and the time of release. These are used in Subsection 6.2 and Appendices D and E for leakage rate calculations. 
Table 5. Radionuclide Source Terms for Release Evaluation

\begin{tabular}{|c|c|l|l|l|l|}
\hline Nuclide & $\begin{array}{c}\text { Avg PWR } \\
\text { Curies/ } \\
\text { Assembly }\end{array}$ & $\begin{array}{l}\text { Avg PWR } \\
\text { Curies/WP }\end{array}$ & Nuclide Totals & $\begin{array}{c}\text { Avg PWR } \\
\text { Curies/ } \\
\text { Assembly }\end{array}$ & \multicolumn{1}{|c|}{$\begin{array}{c}\text { Avg PWR }^{\mathbf{b}} \\
\text { Curies/WP }\end{array}$} \\
\hline $\mathrm{Kr}-85$ & $1.13 \mathrm{E}+03$ & $2.37 \mathrm{E}+04$ & Total Gases & $1.24 \mathrm{E}+03$ & $2.61 \mathrm{E}+04$ \\
\hline $\mathrm{Cs}-137$ & $4.11 \mathrm{E}+04$ & $8.63 \mathrm{E}+05$ & Total Volatiles & $6.83 \mathrm{E}+04$ & $1.43 \mathrm{E}+06$ \\
\hline $\mathrm{Sr}-90$ & $2.72 \mathrm{E}+04$ & $5.71 \mathrm{E}+05$ & Total Fines & $3.24 \mathrm{E}+04$ & $6.81 \mathrm{E}+05$ \\
\hline $\mathrm{Pu}-238$ & $2.29 \mathrm{E}+03$ & $4.81 \mathrm{E}+04$ & Total Crud & $2.35 \mathrm{E}+00$ & $4.93 \mathrm{E}+01$ \\
\hline $\mathrm{Pu}-239$ & $1.77 \mathrm{E}+02$ & $3.72 \mathrm{E}+03$ & & & \\
\hline Co-60 (Crud) & $2.35 \mathrm{E}+00^{\mathrm{c}}$ & $4.93 \mathrm{E}+01$ & & & \\
\hline
\end{tabular}

NOTES: ${ }^{a}$ Source: (Appendix A, Table A-1).

${ }^{b}$ Average Curies per WP $=$ Average Curies per Assembly x 21 Assembly.

${ }^{\mathrm{c}}$ Average Crud per assembly $=140\left(\mu \mathrm{Ci} / \mathrm{cm}^{2}\right) \times 449,003\left(\mathrm{~cm}^{2}\right) \mathrm{e}^{-(0.693 / 5.271) \times 25} \times 10^{-6}(\mathrm{Ci} /(\mu \mathrm{Ci})$.

\subsubsection{Release Fractions}

The following assumptions are made consistent with the release fractions used in ANSI (ANSI N14.5-97 1998, p. 46) and the NRC (NRC 2000, p. 9-12):

- $3 \%$ of the fuel rods are assumed to develop cladding breaches that could cause the release of gases, volatiles, and particulates in the gap region. All radionuclides present in the fuel rod gap are assumed to be released in the event of a cladding breach.

- Of the total fuel assembly radioactive inventory, the following fractions are assumed to be present in the fuel rod gap:

- 0.3 of fission gases

- $2 \times 10^{-4}$ for volatile materials

- $3 \times 10^{-5}$ for fuel particles.

For crud, $15 \%$ of the surface contamination is assumed to become loose from the fuel surfaces under normal conditions. All loose crud is assumed to be available for release.

Since the purpose is to evaluate the detectability of a defective WP leak, the release fractions under normal conditions assumed by the ANSI and NRC are used in this report (Subsection 6.2) to estimate the potential releases.

Table 6 summarizes the source term release fractions that are used to perform the WP release calculations in Subsection 6.2. The release fraction, except for crud, is a fraction of total nuclide inventory within a spent fuel rod, and is applicable only to the failed fuel rods in a WP. 
Table 6. SourceTerm Release Fractions by Radionuclide Group

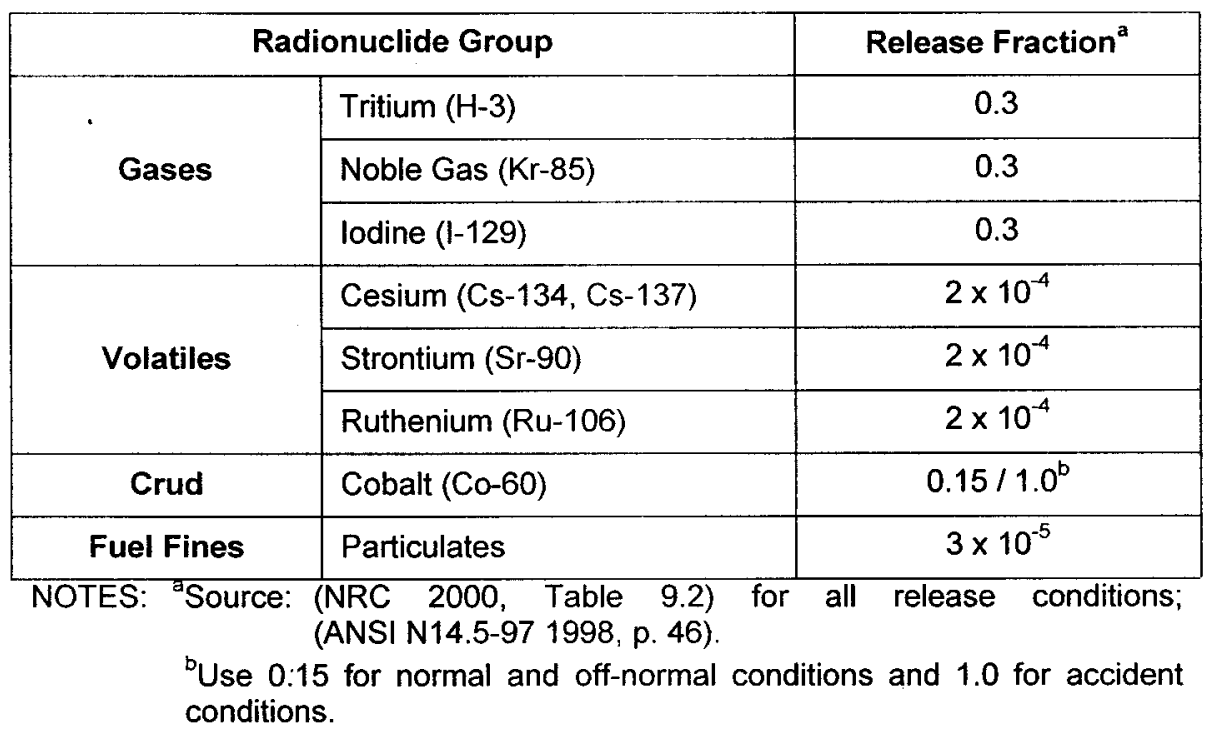

\subsubsection{Leakpath Factor}

A leakpath factor of 0.1 is assumed in calculating particulate radionuclide releases from a WP in Subsection 6.2. This leakpath factor represents the fraction of airborne particulate radionuclides that leaves a WP after the action of depletion mechanisms such as precipitation, gravitational settling of the released particulate material, or agglomeration, through the confinement barrier including partial plugging of the leak hole. The 0.1 leakpath factor is the recommended value in Leakpath Factors for Radionuclide Releases from Breached Confinement Barrier (CRWMS $\mathrm{M} \& \mathrm{O} 2000 \mathrm{e}$, Section 6) for particulate source term released from a WP.

\subsubsection{Radioactive Decay from WP Surface Contamination}

Radioactive decay is assumed negligible in deriving LRCL in Section 3.1.1. This assumption is appropriate because it yields the most restrictive or the smallest LRCL.

\subsubsection{Barometric Pressure}

The barometric pressure inside the repository is assumed to be $890 \mathrm{mBars}$ (or $890 \times 10^{-3} \mathrm{x}$ $0.9869=0.8783 \mathrm{~atm})$. This barometric pressure is based upon data presented in the Ventilation System Radon Review (CRWMS M\&O 2000j, Figure 3). This assumption is appropriate because the data were taken from the Exploratory Studies Facility of the repository and the actual atmospheric pressure would be dependent on the weather condition at the time of release. This assumption is used in Appendix D for calculating potential WP leakage rates. 


\subsection{CRITERIA}

Criteria applicable to this report are taken from the Disposal Container Handling System Description Document (CRWMS M\&O 2000c) and the Monitored Geologic Repository Project Description Document (Curry, P.M. 2001).

The Disposal Container Handling System Description Document (CRWMS M\&O 2000c, Subsection 1.2.1.8) requires that the system shall decontaminate the WP surface to less than (TBD-0169) $\mathrm{dpm} / 100 \mathrm{~cm}^{2}$ prior to delivery to the Waste Emplacement/Retrieval System.

The Monitored Geologic Repository Project Description Document (Curry, P.M. 2001, Subsections 5.3.3, 5.3.4 and 5.3.5) requires that

- For all workers entering radiological control areas of the repository, radiological exposure shall be maintained ALARA, in accordance with an approved radiological protection program.

- Any MGR system or process with an expected exposure to an individual exceeding $250 \mathrm{mrem} / \mathrm{yr}$ or an expected collective exposure exceeding 1 person-rem/yr TEDE, shall receive a formal assessment in accordance with the ALARA program.

- Any MGR system or process where the dose to an individual member of the public is expected to exceed $10 \mathrm{mrem} / \mathrm{yr}$ TEDE from air emissions shall receive a formal assessment in accordance with the ALARA program.

\subsection{CODES AND STANDARDS}

The following codes and standards appear in this report:

\subsubsection{CFR 20}

- 20.1302(b) requires that "A licensee shall show compliance with the annual dose limit in Sec. 20.1301 by (1) Demonstrating by measurement or calculation that the total effective dose equivalent to the individual likely to receive the highest dose from the licensed operation does not exceed the annual dose limit; or (2) Demonstrating that (i) The annual average concentrations of radioactive material released in gaseous and liquid effluents at the boundary of the unrestricted area do not exceed the values specified in Table 2 of Appendix B to Part 20."

- 20.1101(d) requires that "To implement the ALARA requirements of Sec. 20.1101(b), and notwithstanding the requirements in Sec. 20.1301 of this part, a constraint on air emissions of radioactive material to the environment, excluding Radon-222 and its daughters, shall be established by licensees ... such that the individual member of the public likely to receive the highest dose will not be expected to receive a total effective dose equivalent in excess of 10 mrem $(0.1 \mathrm{mSv})$ per year from these emissions." 


\subsubsection{CFR 173.443 Contamination Control.}

(Table 11) Non-Fixed External Radioactive Contamination-Wipe Limits.

\begin{tabular}{|c|c|c|c|}
\hline \multirow{2}{*}{ Contaminant } & \multicolumn{3}{|c|}{ Maximum permissible limits } \\
\cline { 2 - 4 } & $\mathrm{Bq} / \mathrm{cm}^{2}$ & $\mu \mathrm{Ci} / \mathrm{cm}^{2}$ & $\mathrm{Dpm} / \mathrm{cm}^{2}$ \\
\hline $\begin{array}{c}\text { Beta and gamma emitters } \\
\text { and low toxicity alpha } \\
\text { emitters }\end{array}$ & 0.4 & $10^{-5}$ & 22 \\
\hline $\begin{array}{c}\text { All other alpha emitting } \\
\text { radionuclides }\end{array}$ & 0.04 & $10^{-6}$ & 2.2 \\
\hline
\end{tabular}

\subsubsection{ANSI N14.5-97. 1998 .}

American National Standard for Radioactive Materials - Leakage Tests on Packages for Shipment, Annex B.

\subsubsection{ANSI N42.18-1980. 1985.}

Specification and Performance of On-Site Instrumentation for Continuously Monitoring Radioactivity in Effluents, Table 1.

\subsubsection{CFR 63 (66 FR 55732)}

63.111(a)(1) requires that the geological repository operations area must meet the requirements of 10 CFR Part 20. 


\section{USE OF COMPUTER SOFTWARE AND MODELS}

The only computer software related to the development of this report is the qualified radiological safety analysis program RSAC-5 Version 5.2, CSCI: 30067 V5.2 (CRWMS M\&O 1998). As described in Subsection 4.1.3, the result of a calculation performed in the Software Qualification Report for RSAC-5 Version 5.2 the Radiological Safety Analysis Computer Program (CRWMS M\&O 1998, p. 26) was used as basis for selecting the radiologically important radionuclides. No other acquired or developed scientific software, as defined by AP-SI.1Q, Software Management, is used in this report.

Microsoft Excel 97, a spreadsheet computational software, was the only software used in this calculation. Excel was used for release and concentration calculations provided in Appendices A through E. Excel is a commercial spreadsheet program designed to assist in performing calculations. The program provides built-in mathematical functions together with user-defined formulas to automate the calculation process. Output values are automatically updated as input data are added or changed. The user-defined formulas for the spreadsheets provided in Appendices C \& D are described in Subsection 3.2. The formulas used in spreadsheets for leakage rate calculations were verified in accordance with the procedure AP-SI.1Q to be working correctly by hand calculations. Microsoft Excel 97 is an exempt software product in accordance with Section 2.1, of AP-SI.1Q, Software Management.

The computer hardware used in this calculation is a DELL Precision 420 desktop personal computer (CRWMS-M\&O Tag Number 117479). 


\section{INTENTIONALLY LEFT BLANK}




\section{ANALYSIS}

\subsection{DERIVATION OF LRCL}

This Section derives the LRCL on the external surfaces of WPs for acceptance into the subsurface repository. The derived LRCL represent the concentration levels of radioactivity on the external surfaces of a WP that must not be exceeded before the WP is transported to the subsurface repository. The derivation of LRCL is based on the requirement that the annual average concentrations of radioactive material released at the repository shaft exhaust do not exceed the airborne ECL specified in Table 1 (see Subsection 3.1).

The LRCL, $\mathrm{C}_{\mathrm{s}}\left(\mathrm{Ci} / \mathrm{m}^{2}\right)$, are derived based on the methodology described in Subsection 3.1, applicable input parameters in Subsection 4.1, and applicable assumptions in Subsection 4.2. Specifically, Eq. 7 of Subsection 3.1 is used to calculate these $\mathrm{C}_{\mathrm{s}}$ values:

$$
\mathrm{C}_{\mathrm{s}}=(\mathrm{ECL} \times \mathrm{V}) /(\mathrm{A} \times \mathrm{N})
$$

where:

$$
\begin{aligned}
& \left.\mathrm{A}=\text { surface area of the average WP }=32 \mathrm{~m}^{2} \text { (Subsection } 4.2 .10\right) \\
& \left.\mathrm{V}=\text { ventilation flow rate from the exhaust shaft }=715 \mathrm{~m}^{3} / \mathrm{s} \text { (Subsection } 4.2 .15\right) \\
& \mathrm{N}=\text { average number of WPs emplaced per } \mathrm{yr}=605 / \mathrm{yr}(\text { Subsection } 4.2 .13) \\
& \mathrm{ECL}=\text { airborne effluent concentration limit (Table } 1)
\end{aligned}
$$

\subsubsection{Single-Radionuclide LRCL}

The single-radionuclide LRCL are calculated in Table 7 using Eq. 12 above. The calculated LRCL for radionuclides of radiological importance are listed in Table 7, columns (3) and (4), respectively, in $\mu \mathrm{Ci} / \mathrm{cm}^{2}$ and $\mathrm{dpm} / 100 \mathrm{~cm}^{2}$.

Table 7 lists the LRCL derived for individual radionuclides that are radiologically significant (see Subsection 4.1.3). The table can be extended to any other radionuclide of concern that may be present on the WP surface. Gaseous radionuclides such as tritium and $\mathrm{Kr}-85$ are excluded from the table because they would not be present as surface contamination on a WP. The surface contamination limit derived for Co-60 is $1,300,000 \mathrm{dpm} / 100 \mathrm{~cm}^{2}$. This limit may be applied to WPs contaminated with crud materials. The most restrictive LRCL for alpha and beta/gamma emitters present in Table 7 are $520 \mathrm{dpm} / 100 \mathrm{~cm}^{2}$ (Am-214, Pu-238, Pu-239, and Pu-240) and $21,000 \mathrm{dpm} / 100 \mathrm{~cm}^{2}(\mathrm{Pu}-241)$, respectively. The $520 \mathrm{dpm} / 100 \mathrm{~cm}^{2}$ limit derived for alpha emitters is about 2.4 times higher than the maximum permissible limits of $220 \mathrm{dpm} / 100 \mathrm{~cm}^{2}$ listed in Table 11 (Non-Fixed External Radioactive Contamination-Wipe Limits) as specified in the U.S. Department of Transportation's 49 CFR 173.443 for transportation packages (see Subsection 4.4.2). The $21,000 \mathrm{dpm} / 100 \mathrm{~cm}^{2}$ limit derived for beta/gamma emitters is about 9.5 times higher than the maximum permissible limits of $2,200 \mathrm{dpm} / 100 \mathrm{~cm}^{2}$ also listed in Table 11 of 49 CFR 173.443. It should be noted that for exclusive use transport, as stated in 49 CFR 173.443, 10 times the Table 11 limits may be applied. 
The derived single-radionuclide LRCL in Table 7 should be considered as the "limiting levels" for the radionuclides of concern. During confirmation survey of a WP, the most restrictive LRCL for alpha and beta/gamma emitters as presented in Table 7 may be used to demonstrate compliance.

Table 7. Derivation of LRCL

\begin{tabular}{|c|c|c|c|c|}
\hline Nuclide & $\begin{array}{c}\text { (1) } \\
\text { Airborne ECL }\end{array}$ & $\begin{array}{c}\text { (2) } \\
\text { Derived LRCL }\end{array}$ & $\begin{array}{c}\text { (3) } \\
\text { Derived LRCL }\end{array}$ & $\begin{array}{c}\text { (4) } \\
\text { Derived LRCL \& } \\
\text { Type of Radiation } \\
\text { emitter }\end{array}$ \\
\hline Co-60 & $\mathrm{Ci} / \mathrm{m}^{3}$ & $\mathrm{Ci} / \mathrm{m}^{2}$ & $\mu \mathrm{Ci} / \mathrm{cm}^{2}$ & $\mathrm{dpm} / 100 \mathrm{~cm}^{2}$ \\
\hline $\mathrm{Sr}-90$ & $5.0 \mathrm{E}-11$ & $5.8 \mathrm{E}-05$ & $5.8 \mathrm{E}-03$ & $1,300,000(\beta-\gamma)$ \\
\hline $\mathrm{Cs}-137$ & $6.0 \mathrm{E}-12$ & $7.0 \mathrm{E}-06$ & $7.0 \mathrm{E}-04$ & $160,000(\beta-\gamma)$ \\
\hline $\mathrm{Pu}-238$ & $2.0 \mathrm{E}-10$ & $2.3 \mathrm{E}-04$ & $2.3 \mathrm{E}-02$ & $5,200,000(\beta-\gamma)$ \\
\hline $\mathrm{Pu}-239$ & $2.0 \mathrm{E}-14$ & $2.3 \mathrm{E}-08$ & $2.3 \mathrm{E}-06$ & $520(\alpha)$ \\
\hline $\mathrm{Pu}-240$ & $2.0 \mathrm{E}-14$ & $2.3 \mathrm{E}-08$ & $2.3 \mathrm{E}-06$ & $520(\alpha)$ \\
\hline $\mathrm{Pu}-241$ & $2.0 \mathrm{E}-14$ & $2.3 \mathrm{E}-08$ & $2.3 \mathrm{E}-06$ & $520(\alpha)$ \\
\hline $\mathrm{Am}-241$ & $8.0 \mathrm{E}-13$ & $9.3 \mathrm{E}-07$ & $9.3 \mathrm{E}-05$ & $21,000(\beta-\gamma)$ \\
\hline $\mathrm{Cm}-244$ & $2.0 \mathrm{E}-14$ & $2.3 \mathrm{E}-08$ & $2.3 \mathrm{E}-06$ & $520(\alpha)$ \\
\hline & $3.0 \mathrm{E}-14$ & $3.5 \mathrm{E}-08$ & $3.5 \mathrm{E}-06$ & $780(\alpha)$ \\
\hline
\end{tabular}

NOTES: (1) Table 1.

(2) Eg. 12: (1) $\left.\times 715\left(\mathrm{~m}^{3} / \mathrm{s}\right) \times 3600(\mathrm{~s} / \mathrm{hr}) \times 24(\mathrm{hr} / \mathrm{d}) \times 365(\mathrm{~d} / \mathrm{yr})\right) /[605(\mathrm{WP} / \mathrm{yr}) \times 32$

(3) $(2) \times 1 \mathrm{E} 6(\mu \mathrm{Ci} / \mathrm{Ci}) / 1 \mathrm{E} 4\left(\mathrm{~cm}^{2} / \mathrm{m}^{2}\right)$.

(4) (3) $\times 2.22 \mathrm{E} 6(\mathrm{dpm} / \mu \mathrm{Ci}) \times 100 \mathrm{~cm}^{2}$.

\subsubsection{ALARA Evaluation}

To demonstrate that the derived LRCL will be ALARA, the annual offsite and onsite individual doses are estimated in this section and compared with the applicable dose requirements described in Subsection 4.3. Dose estimates are made assuming that the average contamination level on the external surfaces of each WP is at the LRCL.

\subsubsection{Offsite Maximum Individual Dose}

An offsite maximum individual dose is estimated assuming an individual residing at $8000 \mathrm{~m}$ from the release point (Assumption 4.2.4) and the maximum chronic atmospheric dispersion factor $\left(3.19 \mathrm{E}-7 \mathrm{~s} / \mathrm{m}^{3}\right)$ for ground level releases (Assumption 4.2.5). Based upon the maximum allowable annual release corresponding to a limiting ECL dose of $50 \mathrm{mrem} / \mathrm{yr}$ at the exhaust, the estimated committed effective dose equivalent (CEDE) to the exposed offsite individual is calculated to be $0.011 \mathrm{mrem} / \mathrm{yr}\left(50 \mathrm{mrem} / \mathrm{yr} \times 3.19 \mathrm{E}-7 \mathrm{~s} / \mathrm{m}^{3} \times 715 \mathrm{~m}^{3} / \mathrm{s}\right)$. This dose is much less than the $10 \mathrm{mrem} / \mathrm{yr}$ dose requirement for public exposure; therefore, the derived contamination limits would comply with the ALARA public dose requirement (Subsection 4.3). 


\subsubsection{Worker Dose}

The worker dose is calculated by the equation provided in Regulatory Guide 8.34 (1992, Subsection 3.3) as:

$$
\mathrm{H}_{\mathrm{i}, \mathrm{E}}=5 \mathrm{C}_{\mathrm{i}} \mathrm{t} / 2000 \mathrm{DAC}_{\mathrm{i}}
$$

where: $\mathrm{H}_{\mathrm{i}, \mathrm{E}} \quad=$ committed effective dose equivalent from radionuclide $\mathrm{i}$ (rems)

$\mathrm{C}_{\mathrm{I}} \quad=$ airborne concentration of radionuclide $\mathrm{i}$ to which the worker is exposed $\left(\mu \mathrm{Ci} / \mathrm{cm}^{3}\right.$ or $\left.\mathrm{Ci} / \mathrm{m}^{3}\right)$

$\mathrm{DAC}_{\mathrm{i}}=$ derived air concentration for nuclide $\mathrm{i}\left(\mu \mathrm{Ci} / \mathrm{cm}^{3}\right.$ or Ci $/ \mathrm{m}^{3}$, Table 1$)$

$\mathrm{T}=$ duration of the exposure (2000 hours, Subsection 4.2.8)

$2000=$ number of hours in a work year

$5=$ committed effective dose equivalent from annual intake of 1 annual limit on intake or 2000 DAC-hours (rems)

\subsection{Surface Worker Dose}

The annual maximum dose to a hypothetical surface worker is calculated assuming this individual works full time $(2000 \mathrm{hr} / \mathrm{yr}$, Subsection 4.2 .8$)$ at $100 \mathrm{~m}$ from the exhaust shaft (Subsection 4.2.4), the maximum chronic atmospheric dispersion factor $\left(4.77 \mathrm{E}-4 \mathrm{~s} / \mathrm{m}^{3}\right.$ ) for ground level releases (Subsection 4.2.5) and the residual contamination level on WP are at the LRCL shown in Table 7.

The annual average dose to a surface worker is calculated assuming this individual works full time $(2000 \mathrm{hr} / \mathrm{yr}$, Subsection 4.2 .8$)$ at $3 \mathrm{~km}$ from the exhaust shaft (Subsection 4.2.4), the maximum chronic atmospheric dispersion factor $\left(1.23 \mathrm{E}-6 \mathrm{~s} / \mathrm{m}^{3}\right)$ for ground level releases (Subsection 4.2.5), and the residual contamination level on WP are at the LRCL shown in Table 7.

The calculation of annual doses (in mrem/yr) received by the average and maximum surface workers using Eq. 13 above is shown in Table 8. The estimated maximum and average annual surface worker doses from the contamination present on the WPs at the LRCL listed in Table 7 are $14 \mathrm{mrem} / \mathrm{yr}$ and $0.035 \mathrm{mrem} / \mathrm{yr}$, respectively (shown in columns (4) and (5) of Table 8, respectively). The maximally exposed surface worker dose is about $6 \%$ of the $250 \mathrm{mrem} / \mathrm{yr}$ ALARA dose criterion; therefore, a formal ALARA assessment is not required (Subsection 4.3).

\subsection{Subsurface Worker Dose}

The annual dose to a subsurface worker is calculated assuming that the individual worker works full time at the repository Access Main (Subsection 4.2.8), the ventilation airflow of $45.6 \mathrm{~m}^{3} / \mathrm{s}$ (Subsection 4.2.14), and the residual contamination level on all WPs is at the LRCL shown in Table 7. Airborne radioactive contamination in the Access Main could result from mechanical disturbance of the deposited material on the WPs during transport and entrainment in moving air adjacent to the surface. The resuspension rate of the deposited contamination has been conservatively assumed to be at 0.00004 per hour (Assumption 4.2.6). 
The calculation of annual doses (in mrem/yr) received by the subsurface worker using Eq. 13 is shown in Table 8. The estimated annual worker dose from the contamination present on the WPs at the concentration limits listed in Table 7 is $0.36 \mathrm{mrem} / \mathrm{yr}$ maximum (shown in column (7) of Table 8). This dose is less than $1 \%$ of the $250 \mathrm{mrem} / \mathrm{yr}$ ALARA dose criterion for the maximally exposed worker; therefore, a formal ALARA assessment is not required (Subsection $4.3)$.

\subsubsection{Total Collective Worker Dose}

The total collective repository worker dose is calculated by summing the total collective subsurface worker dose and the total collective surface worker dose. The total collective subsurface worker dose is calculated by multiplying the total number of subsurface workers of 90 (Assumption 4.2.9) that is required during the waste emplacement period and the individual subsurface worker dose of $0.00036 \mathrm{rem} / \mathrm{yr}$ calculated in Table 8 . The total collective subsurface worker dose therefore is $90 \times 0.00036=0.032$ person-rem $/ y r$. The total collective surface worker dose is calculated by multiplying the total number of surface workers of 1305 (Assumption 4.2.9) estimated for the waste emplacement period and the average individual surface worker dose of $0.000035 \mathrm{rem} / \mathrm{yr}$ calculated in Table 8 . The total collective surface worker dose therefore is $1305 \times 0.000035=0.046$ person-rem/yr. Summing up the total collective subsurface and surface worker doses, the total collective repository worker dose is 0.031 person-rem $/ \mathrm{yr}+0.046 \mathrm{person}-\mathrm{rem} / \mathrm{yr}=0.078 \mathrm{person}-\mathrm{rem} / \mathrm{yr}$. This total collective dose is less than $8 \%$ of the 1 person-rem/yr ALARA collective dose criterion; therefore, a formal ALARA assessment is not required (Subsection 4.3).

Table 8. Worker ALARA Dose Calculation

\begin{tabular}{|c|c|c|c|c|c|c|c|}
\hline Nuclide & $\begin{array}{c}\text { (1) } \\
\text { Derived } L R C L\end{array}$ & $\begin{array}{l}(2) \\
\text { DAC }\end{array}$ & $\begin{array}{c}(3) \\
\text { Radionuclide } \\
\text { Concentration } \\
\text { at } 100 \mathrm{~m}\end{array}$ & $\begin{array}{c}(4) \\
\text { Maximum Surface } \\
\text { Worker Dose at } \\
100 \mathrm{~m} \text { (CEDE) }\end{array}$ & $\begin{array}{c}(5) \\
\text { Average Surface } \\
\text { Worker Dose at } 3 \\
\text { km (CEDE) }\end{array}$ & \begin{tabular}{|c|}
$(6)$ \\
Radionuclide \\
Concentration \\
in Access \\
Main
\end{tabular} & $\begin{array}{c}\text { (7) } \\
\text { Subsurface } \\
\text { Worker Dose } \\
\text { (CEDE) }\end{array}$ \\
\hline & $\left(\mathrm{Ci} / \mathrm{m}^{2}\right)$ & $\left(\mathrm{Ci} / \mathrm{m}^{3}\right)$ & $\left(\mathrm{Ci} / \mathrm{m}^{3}\right)$ & (mrem/yr) & (mrem/yr) & $\left(\mathrm{Ci} / \mathrm{m}^{3}\right)$ & (mrem/yr) \\
\hline Co-60 & 5.8E-05 & $1.0 \mathrm{E}-08$ & 1.7E-11 & $8.5 E+00$ & 2.2E-02 & $4.5 E-13$ & 2.3E-01 \\
\hline Sr-90 & 7.0E-06 & 2.0E-09 & $2.0 \mathrm{E}-12$ & $5.1 E+00$ & $1.3 E-02$ & $5.4 E-14$ & $1.4 E-01$ \\
\hline Cs-137 & 2.3E-04 & $6.0 \mathrm{E}-08$ & $6.8 \mathrm{E}-11$ & $5.7 \mathrm{E}+00$ & $1.5 \mathrm{E}-02$ & $1.8 \mathrm{E}-12$ & $1.5 \mathrm{E}-01$ \\
\hline Pu-238 & 2.3E-08 & $3.0 E-12$ & $6.8 \mathrm{E}-15$ & $1.1 E+01$ & $2.9 \mathrm{E}-02$ & $1.8 \mathrm{E}-16$ & 3.0E-01 \\
\hline Pu-239 & $2.3 \mathrm{E}-08$ & $3.0 \mathrm{E}-12$ & $6.8 \mathrm{E}-15$ & $1.1 \mathrm{E}+01$ & $2.9 \mathrm{E}-02$ & $1.8 \mathrm{E}-16$ & $3.0 \mathrm{E}-01$ \\
\hline $\mathrm{Pu}-240$ & $2.3 \mathrm{E}-08$ & $3.0 \mathrm{E}-12$ & $6.8 \mathrm{E}-15$ & 1.1E+01 & $2.9 \mathrm{E}-02$ & $1.8 \mathrm{E}-16$ & $3.0 \mathrm{E}-01$ \\
\hline $\mathrm{Pu}-241$ & $9.3 E-07$ & $1.0 \mathrm{E}-10$ & $2.7 \mathrm{E}-13$ & $1.4 \mathrm{E}+01(\max )$ & $3.5 \mathrm{E}-02$ (max) & $7.3 E-15$ & 3.6E-01(max) \\
\hline$A m-241$ & $2.3 \mathrm{E}-08$ & $3.0 \mathrm{E}-12$ & $6.8 \mathrm{E}-15$ & $1.1 E+01$ & $2.9 \mathrm{E}-02$ & $1.8 \mathrm{E}-16$ & 3.0E-01 \\
\hline $\mathrm{Cm}-244$ & $3.5 \mathrm{E}-08$ & $5.0 \mathrm{E}-12$ & $1.0 \mathrm{E}-14$ & $1.0 E+01$ & $2.6 E-02$ & 2.7E-16 & 2.7E-01 \\
\hline
\end{tabular}

(1) Table 7, column (2)

(2) Table 1 (10 CFR 20, Appendix B, Table 1, Column 2)

(3) (1) $\times 605(\mathrm{WP} / \mathrm{yr}) \times 32\left(\mathrm{~m}^{2} \mathrm{NWP}\right) \times 3.17 \mathrm{E}-8(\mathrm{yr} / \mathrm{s}) \times 4.77 \mathrm{E}-4\left(\mathrm{~s} / \mathrm{m}^{3}\right)$

(4) Eq. 13 (with $t=2000): 5(\mathrm{rem} / \mathrm{yr}) \times(3) /(2) \times 1000(\mathrm{mrem} / \mathrm{rem})$

(5) (4) $\times 1.23 \mathrm{E}-6\left(\mathrm{~s} / \mathrm{m}^{3}\right) / 4.77 \mathrm{E}-4\left(\mathrm{~s} / \mathrm{m}^{3}\right)$

(6) (1) $\times 32\left(\mathrm{~m}^{2} \mathrm{MP}\right) \times 0.00004(1 / \mathrm{hr}) / 3600(\mathrm{~s} / \mathrm{hr}) / 45.6\left(\mathrm{~m}^{3} / \mathrm{s}\right)$

(7) Eq. 13 (with $\mathrm{t}=2000): 5(\mathrm{rem} / \mathrm{yr}) \times(6) /(2) \times 1000(\mathrm{mrem} / \mathrm{rem})$ 


\subsection{WP RELEASE AND ITS DETECTABILITY}

During the preclosure phase of the subsurface facility, an emplaced WP could become breached. The breached WP may release its gaseous, volatile, and particulate radionuclide contents to the subsurface facility. To control potential contamination inside the subsurface facility, a sensitive and well-designed airborne radioactivity monitoring system would be required for detecting leaks from WPs.

Four illustrating examples are used in this section for estimating potential WP leaks and their detectability. The potential releases are estimated based on the method described in Subsection 3.2, applicable design parameters in Subsection 4.1, and applicable assumptions in Subsection 4.2. The sensitivity of using air samples to detect potential leaks is evaluated by comparing the released concentrations to the MLD for radionuclides in effluent streams as specified in Table 4. The 21-PWR WP is used as a representative WP configuration for estimating the source terms and their potential release rates (Subsection 4.1.2).

The first example is used to determine the leak-tight hole diameter. The second example estimates potential internal pressure buildup inside a WP due to rupture of fuel rods. The third example is used to examine the sensitivity of leakage rate to hole size and WP temperature. The fourth example is used to evaluate radionuclide concentrations in the ventilation raise arising from potential leaks and their detectability.

\subsubsection{Example 1: Leak-tight Hole Diameter}

Leak-tight is defined in ANSI N14.5-97 $(1998$, p. 1) as a degree of package containment that in a practical sense precludes any significant release of radioactive materials. This degree of containment is achieved by demonstration of a leakage rate less than or equal to $1 \times 10^{-7} \mathrm{ref} . \mathrm{cm}^{3} / \mathrm{s}$, of air at an upstream pressure of 1 atmosphere (atm) absolute (abs) and a downstream pressure of $0.01 \mathrm{~atm}$ abs or less. The leakage rate of $1 \mathrm{ref} . \mathrm{cm}^{3} / \mathrm{s}$ is defined as a volume of one cubic centimeter of dry air per second at 1 atmosphere absolute pressure and $25^{\circ} \mathrm{C}$. Table 9 was generated using air as the medium and equations presented in Subsection 3.2. The detailed calculations of air leakage rates are provided in Appendix B.

Table 9. Air Leakage Rates $\left(\mathrm{cm}^{3} / \mathrm{s}\right)$ under Reference Conditions

\begin{tabular}{|c|c|}
\hline $\begin{array}{c}\text { Leak Hole Diameter } \\
(\mathbf{c m})\end{array}$ & $\begin{array}{c}\text { Leakage Rate } \\
\left(\mathrm{cm}^{3} / \mathbf{s}\right)\end{array}$ \\
\hline $1.00 \mathrm{E}-05$ & $1.82 \mathrm{E}-12$ \\
\hline $1.00 \mathrm{E}-04$ & $2.69 \mathrm{E}-09$ \\
\hline $2.82 \mathrm{E}-04$ & $9.95 \mathrm{E}-08$ \\
\hline $1.00 \mathrm{E}-03$ & $1.13 \mathrm{E}-05$ \\
\hline $1.00 \mathrm{E}-02$ & $9.79 \mathrm{E}-02$ \\
\hline $1.00 \mathrm{E}-01$ & $9.63 \mathrm{E}+02$ \\
\hline
\end{tabular}

Source: Appendix B Table B-2 
The result of this example indicates that any leak holes with diameters less than or equal to $0.00028 \mathrm{~cm}$ may be specified as leak-tight according to the above definition.

\subsubsection{Example 2: WP Internal Pressure}

Pressure difference is the driving force for a WP leak. This example estimates potential internal pressure buildup inside a WP due to rupture of fuel rods. The method and parameters used to calculate the internal pressure in the 21-PWR WP are described in Preclosure Design Basis Events Related to Waste Packages (CRWMS M\&O 2000f, Attachment. III).

The internal pressure in the WP is calculated according to the ideal gas law. The detail of the calculation performed is shown in Appendix C. The results of the calculations are summarized in Table 10. The results indicate that WP internal pressure increases with increasing temperature and fuel rupture rate. Increasing fuel rupture rate from $3 \%$ to $100 \%$ would increase the internal pressure by a factor of 3.4. For the same fuel rupture rate, increasing fuel temperature from $25^{\circ} \mathrm{C}$ to $600^{\circ} \mathrm{C}$ would increase the internal pressure by a factor of about 3 .

Table 10. WP Internal Pressure (Pa) as a Function of Temperature and \% Fuel Rupture

\begin{tabular}{|c|c|c|c|c|c|}
\hline & \multicolumn{5}{|c|}{$\%$ Fuel Rupture } \\
\hline Temperature $\left({ }^{\circ} \mathrm{C}\right)$ & $100 \%$ & $50 \%$ & $25 \%$ & $3 \%$ & $10 \%$ \\
\hline 25 & $3.78 \mathrm{E}+05$ & $2.42 \mathrm{E}+05$ & $1.72 \mathrm{E}+05$ & $1.30 \mathrm{E}+05$ & $1.10 \mathrm{E}+05$ \\
\hline 50 & $4.10 \mathrm{E}+05$ & $2.62 \mathrm{E}+05$ & $1.87 \mathrm{E}+05$ & $1.41 \mathrm{E}+05$ & $1.19 \mathrm{E}+05$ \\
\hline 100 & $4.73 \mathrm{E}+05$ & $3.03 \mathrm{E}+05$ & $2.16 \mathrm{E}+05$ & $1.63 \mathrm{E}+05$ & $1.38 \mathrm{E}+05$ \\
\hline 200 & $6.00 \mathrm{E}+05$ & $3.84 \mathrm{E}+05$ & $2.73 \mathrm{E}+05$ & $2.06 \mathrm{E}+05$ & $1.74 \mathrm{E}+05$ \\
\hline 300 & $7.27 \mathrm{E}+05$ & $4.65 \mathrm{E}+05$ & $3.31 \mathrm{E}+05$ & $2.50 \mathrm{E}+05$ & $2.11 \mathrm{E}+05$ \\
\hline 350 & $7.90 \mathrm{E}+05$ & $5.06 \mathrm{E}+05$ & $3.60 \mathrm{E}+05$ & $2.71 \mathrm{E}+05$ & $2.30 \mathrm{E}+05$ \\
\hline 400 & $8.53 \mathrm{E}+05$ & $5.46 \mathrm{E}+05$ & $3.89 \mathrm{E}+05$ & $2.93 \mathrm{E}+05$ & $2.48 \mathrm{E}+05$ \\
\hline 500 & $9.80 \mathrm{E}+05$ & $6.28 \mathrm{E}+05$ & $4.47 \mathrm{E}+05$ & $3.37 \mathrm{E}+05$ & $2.85 \mathrm{E}+05$ \\
\hline 570 & $1.07 \mathrm{E}+06$ & $6.84 \mathrm{E}+05$ & $4.87 \mathrm{E}+05$ & $3.67 \mathrm{E}+05$ & $3.11 \mathrm{E}+05$ \\
\hline 600 & $1.11 \mathrm{E}+06$ & $7.09 \mathrm{E}+05$ & $5.05 \mathrm{E}+05$ & $3.80 \mathrm{E}+05$ & $3.22 \mathrm{E}+05$ \\
\hline
\end{tabular}

NOTES: Source: Appendix C Table C-2

Pressure unit $\mathrm{Pa}=$ Pascal

\subsubsection{Example 3: WP Leakage Rate}

This example is used to examine the sensitivity of leakage rate to hole size and WP temperature. For illustration purposes, $3 \%$ of the fuel rods are assumed to develop cladding breaches that could cause the release of gases, volatiles, and particulates in the gap region (Assumption 4.2.17).

Table 11 was generated using equations presented in Subsection 3.2, and the applicable design parameters and assumptions provided in Subsections 4.1 and 4.2, respectively. The details of the calculations are shown in Appendix D. A graphical representation of the leakage rate calculations is shown in Figure 1.

The conclusion reached from Figure 1 is that leakage rate is significantly more sensitive to variations in leakage hole size than to WP temperature. 
Table 11. 21-PWR WP Leakage Rates

\begin{tabular}{|c|c|c|c|c|c|c|c|}
\hline $\begin{array}{c}\text { Temperature } \\
\left({ }^{\circ} \mathrm{C}\right)\end{array}$ & $\begin{array}{c}\text { Leak Hole } \\
\text { Diameter } \\
(\mathbf{c m})\end{array}$ & $\begin{array}{c}\text { Leakage } \\
\text { Rate }\left(\mathrm{cm}^{3} / \mathbf{s}\right)\end{array}$ & $\begin{array}{c}\text { Gas Leak } \\
\text { Rate (Ci/s) }\end{array}$ & $\begin{array}{c}\text { Volatile } \\
\text { Leak Rate } \\
(\mathrm{Ci} / \mathbf{s})\end{array}$ & $\begin{array}{c}\text { Fine Leak } \\
\text { Rate (Ci/s) }\end{array}$ & $\begin{array}{c}\text { Crud Leak } \\
\text { Rate }(\mathrm{Ci} / \mathbf{s})\end{array}$ & $\begin{array}{c}\text { Total Leak } \\
\text { Rate (Ci/s) }\end{array}$ \\
\hline \multirow{5}{*}{300} & $1.00 \mathrm{E}-05$ & $3.87 \mathrm{E}-12$ & $2.08 \mathrm{E}-16$ & $7.60 \mathrm{E}-19$ & $5.41 \mathrm{E}-20$ & $6.53 \mathrm{E}-19$ & $2.09 \mathrm{E}-16$ \\
\cline { 2 - 8 } & $1.00 \mathrm{E}-04$ & $4.79 \mathrm{E}-09$ & $2.57 \mathrm{E}-13$ & $9.40 \mathrm{E}-16$ & $6.69 \mathrm{E}-17$ & $8.08 \mathrm{E}-16$ & $2.59 \mathrm{E}-13$ \\
\cline { 2 - 8 } & $1.00 \mathrm{E}-03$ & $1.39 \mathrm{E}-05$ & $7.48 \mathrm{E}-10$ & $2.74 \mathrm{E}-12$ & $1.95 \mathrm{E}-13$ & $2.35 \mathrm{E}-12$ & $7.53 \mathrm{E}-10$ \\
\cline { 2 - 8 } & $1.00 \mathrm{E}-02$ & $1.05 \mathrm{E}-01$ & $5.66 \mathrm{E}-06$ & $2.07 \mathrm{E}-08$ & $1.47 \mathrm{E}-09$ & $1.78 \mathrm{E}-08$ & $5.70 \mathrm{E}-06$ \\
\cline { 2 - 8 } & $1.00 \mathrm{E}-01$ & $1.02 \mathrm{E}+03$ & $5.48 \mathrm{E}-02$ & $2.00 \mathrm{E}-04$ & $1.43 \mathrm{E}-05$ & $1.72 \mathrm{E}-04$ & $5.51 \mathrm{E}-02$ \\
\hline \multirow{5}{*}{350} & $1.00 \mathrm{E}-05$ & $4.27 \mathrm{E}-12$ & $2.29 \mathrm{E}-16$ & $8.38 \mathrm{E}-19$ & $5.97 \mathrm{E}-20$ & $7.20 \mathrm{E}-19$ & $2.31 \mathrm{E}-16$ \\
\cline { 2 - 8 } & $1.00 \mathrm{E}-04$ & $5.23 \mathrm{E}-09$ & $2.81 \mathrm{E}-13$ & $1.03 \mathrm{E}-15$ & $7.32 \mathrm{E}-17$ & $8.83 \mathrm{E}-16$ & $2.83 \mathrm{E}-13$ \\
\cline { 2 - 8 } & $1.00 \mathrm{E}-03$ & $1.49 \mathrm{E}-05$ & $7.98 \mathrm{E}-10$ & $2.92 \mathrm{E}-12$ & $2.08 \mathrm{E}-13$ & $2.51 \mathrm{E}-12$ & $8.03 \mathrm{E}-10$ \\
\cline { 2 - 8 } & $1.00 \mathrm{E}-02$ & $1.11 \mathrm{E}-01$ & $5.97 \mathrm{E}-06$ & $2.19 \mathrm{E}-08$ & $1.56 \mathrm{E}-09$ & $1.88 \mathrm{E}-08$ & $6.01 \mathrm{E}-06$ \\
\cline { 2 - 8 } & $1.00 \mathrm{E}-01$ & $1.08 \mathrm{E}+03$ & $5.77 \mathrm{E}-02$ & $2.11 \mathrm{E}-04$ & $1.50 \mathrm{E}-05$ & $1.81 \mathrm{E}-04$ & $5.81 \mathrm{E}-02$ \\
\hline \multirow{5}{*}{500} & $1.00 \mathrm{E}-05$ & $5.32 \mathrm{E}-12$ & $2.86 \mathrm{E}-16$ & $1.05 \mathrm{E}-18$ & $7.44 \mathrm{E}-20$ & $8.98 \mathrm{E}-19$ & $2.88 \mathrm{E}-16$ \\
\cline { 2 - 8 } & $1.00 \mathrm{E}-04$ & $6.39 \mathrm{E}-09$ & $3.43 \mathrm{E}-13$ & $1.26 \mathrm{E}-15$ & $8.94 \mathrm{E}-17$ & $1.08 \mathrm{E}-15$ & $3.45 \mathrm{E}-13$ \\
\cline { 2 - 8 } & $1.00 \mathrm{E}-03$ & $1.71 \mathrm{E}-05$ & $9.17 \mathrm{E}-10$ & $3.36 \mathrm{E}-12$ & $2.39 \mathrm{E}-13$ & $2.88 \mathrm{E}-12$ & $9.23 \mathrm{E}-10$ \\
\cline { 2 - 8 } & $1.00 \mathrm{E}-02$ & $1.24 \mathrm{E}-01$ & $6.65 \mathrm{E}-06$ & $2.44 \mathrm{E}-08$ & $1.73 \mathrm{E}-09$ & $2.09 \mathrm{E}-08$ & $6.70 \mathrm{E}-06$ \\
\cline { 2 - 7 } & $1.00 \mathrm{E}-01$ & $1.19 \mathrm{E}+03$ & $6.40 \mathrm{E}-02$ & $2.34 \mathrm{E}-04$ & $1.67 \mathrm{E}-05$ & $2.01 \mathrm{E}-04$ & $6.45 \mathrm{E}-02$ \\
\hline
\end{tabular}

Source: Appendix D Table D-4.

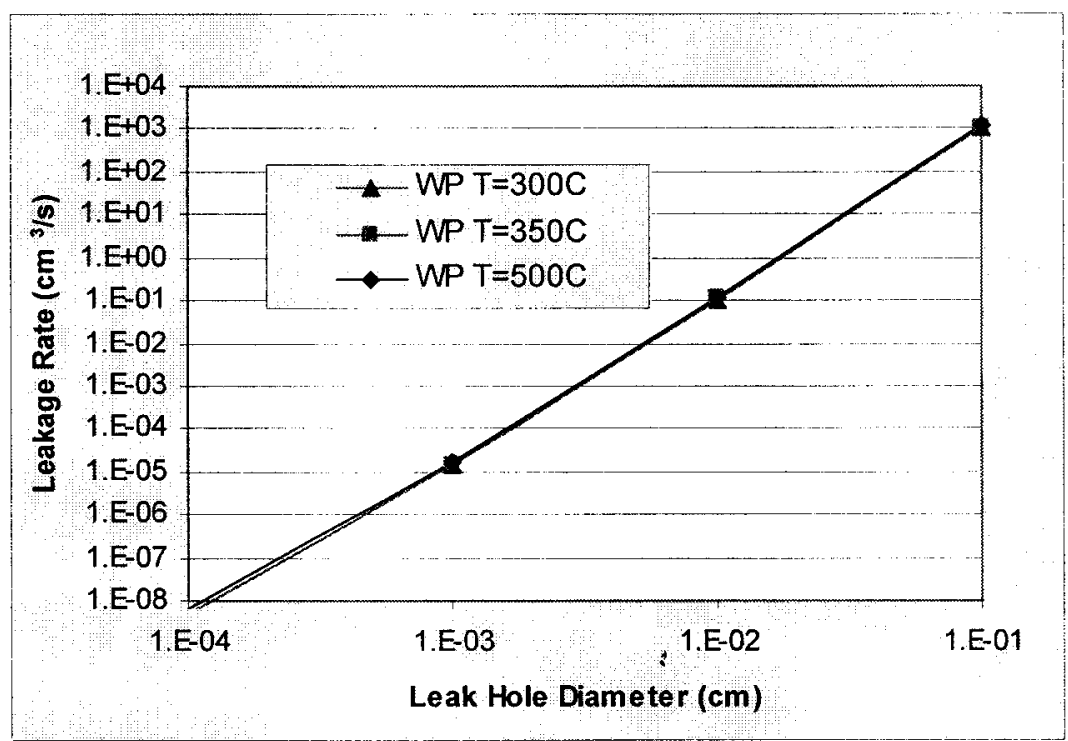

Figure 1. WP Leakage Rate as a Function of Hole size and Temperature 


\subsubsection{Example 4: Radionuclide Concentration and Detectability}

To control potential contamination at the subsurface repository and to detect prematurely failed WPs, a sensitive and well-designed airborne radioactivity monitoring system would be required for detecting WP leaks. The detection of failed WPs may be required in order to provide reasonable assurance that the integrity of WP is intact prior to MGR closure. A sensitive and fast response detection system may be necessary because the radioactive gaseous or particulate matter could quickly escape in the event that the WP develops a flaw. This example evaluates the detectability of radionuclide concentrations in the ventilation raise arising from potential WP leaks. The ventilation raise is selected because it channels the exhaust air directly from emplacement drifts to the repository exhaust.

The sensitivity of using air sampling to detect potential leaks is evaluated by comparing the released concentrations in the raise to the minimum levels of detectability for radionuclides in effluent streams as specified in Table 4. Table 12 summarizes the radionuclide concentrations generated using the volumetric leakage rates listed in Table 11, the radionuclide source terms listed in Table 5, and the raise airflow rate of $30 \mathrm{~m}^{3} / \mathrm{s}$ described in 4.1.1. The details of the calculation performed are provided in Appendix E.

A comparison of the raise concentrations and the minimum level of detectabilities shown in Table 12 indicates that a continuous air monitoring system may not be sensitive enough to detect the presence of any radionuclides from small WP leaks (e.g., a leak hole diameter smaller than about $0.001-0.01 \mathrm{~cm}$ ). The minimum levels of detectability listed in Table 12 refer to the sensitivities for detection of an effluent stream for individual nuclides and represent what is reasonably obtainable consistent with state-of-the-art measurements. The numerical values apply at the detector locations and use continuous monitoring instruments. Since significant amounts of radon concentrations are expected to be present in the ventilation raises (averages ranged from 29 to $43 \mathrm{pCi} / \mathrm{L}, \mathrm{CRWMS} \mathrm{M} \& \mathrm{O}, 2000 \mathrm{~h}, \mathrm{p}$. 24), the minimum level of detectability will need to be re-assessed with consideration given to interference from these natural sources. 
Table 12. Estimated Radionuclide Concentration in Raise

\begin{tabular}{|c|c|c|c|c|c|c|c|}
\hline \multirow{2}{*}{$\begin{array}{c}\text { Temperature } \\
\left({ }^{\circ} \mathrm{C}\right)\end{array}$} & \multirow{2}{*}{$\begin{array}{l}\text { Leak Hole } \\
\text { Diameter } \\
\text { (cm) }\end{array}$} & \multicolumn{6}{|c|}{ Radionuclide Concentration in Raise $\left(\mathrm{Ci} / \mathrm{m}^{3}\right)$} \\
\hline & & Kr-85 & Cs-137 & Sr-90 & Pu-238 & Pu-239 & $\begin{array}{l}\text { Co-60 } \\
\text { (Crud) }\end{array}$ \\
\hline \multirow{5}{*}{300} & $1.00 \mathrm{E}-05$ & $6.29 E-18$ & $1.52 \mathrm{E}-20$ & $1.01 \mathrm{E}-20$ & 1.27E-22 & $9.85 E-24$ & $2.18 E-20$ \\
\hline & $1.00 \mathrm{E}-04$ & 7.77E-15 & $1.89 \mathrm{E}-17$ & $1.25 \mathrm{E}-17$ & $1.58 \mathrm{E}-19$ & $1.22 \mathrm{E}-20$ & $2.69 \mathrm{E}-17$ \\
\hline & $1.00 \mathrm{E}-03$ & $2.26 \mathrm{E}-11$ & $5.49 \mathrm{E}-14$ & 3.63E-14 & $4.59 \mathrm{E}-16$ & $3.55 \mathrm{E}-17$ & 7.84E-14 \\
\hline & $1.00 \mathrm{E}-02$ & $1.71 \mathrm{E}-07$ & 4.15E-10 & $2.75 \mathrm{E}-10$ & $3.47 \mathrm{E}-12$ & $2.68 \mathrm{E}-13$ & $5.93 E-10$ \\
\hline & $1.00 \mathrm{E}-01$ & $1.66 \mathrm{E}-03$ & $4.02 \mathrm{E}-06$ & 2.66E-06 & 3.36E-08 & $2.60 \mathrm{E}-09$ & 5.74E-06 \\
\hline \multirow{5}{*}{350} & 1.00E-05 & $6.93 \mathrm{E}-18$ & $1.68 \mathrm{E}-20$ & $1.11 \mathrm{E}-20$ & $1.40 \mathrm{E}-22$ & $1.09 \mathrm{E}-23$ & $2.40 \mathrm{E}-20$ \\
\hline & $1.00 \mathrm{E}-04$ & $8.50 \mathrm{E}-15$ & $2.06 \mathrm{E}-17$ & 1.36E-17 & $1.72 \mathrm{E}-19$ & 1.33E-20 & $2.94 \mathrm{E}-17$ \\
\hline & $1.00 \mathrm{E}-03$ & $2.41 \mathrm{E}-11$ & $5.86 \mathrm{E}-14$ & $3.88 \mathrm{E}-14$ & $4.89 \mathrm{E}-16$ & $3.78 \mathrm{E}-17$ & $8.36 \mathrm{E}-14$ \\
\hline & $1.00 E-02$ & 1.81E-07 & $4.38 E-10$ & $2.90 \mathrm{E}-10$ & $3.66 \mathrm{E}-12$ & $2.83 E-13$ & $6.26 \mathrm{E}-10$ \\
\hline & $1.00 \mathrm{E}-01$ & $1.75 \mathrm{E}-03$ & 4.23E-06 & $2.80 \mathrm{E}-06$ & $3.54 \mathrm{E}-08$ & 2.73E-09 & $6.05 \mathrm{E}-06$ \\
\hline \multirow{5}{*}{500} & $1.00 E-05$ & $8.64 E-18$ & $2.10 \mathrm{E}-20$ & 1.39E-20 & $1.75 \mathrm{E}-22$ & 1.35E-23 & $2.99 \mathrm{E}-20$ \\
\hline & $1.00 \mathrm{E}-04$ & $1.04 \mathrm{E}-14$ & $2.52 \mathrm{E}-17$ & $1.67 \mathrm{E}-17$ & $2.10 \mathrm{E}-19$ & 1.63E-20 & $3.59 \mathrm{E}-17$ \\
\hline & $1.00 \mathrm{E}-03$ & 2.77E-11 & $6.73 E-14$ & $4.45 \mathrm{E}-14$ & $5.62 \mathrm{E}-16$ & $4.35 \mathrm{E}-17$ & $9.61 \mathrm{E}-14$ \\
\hline & 1.00E-02 & 2.01E-07 & $4.88 \mathrm{E}-10$ & $3.23 E-10$ & $4.08 \mathrm{E}-12$ & $3.16 \mathrm{E}-13$ & $6.97 \mathrm{E}-10$ \\
\hline & $1.00 \mathrm{E}-01$ & 1.94E-03 & 4.70E-06 & 3.11E-06 & 3.93E-08 & 3.04E-09 & $6.71 \mathrm{E}-06$ \\
\hline \multicolumn{2}{|c|}{$\begin{array}{l}\text { Min. Level Detectability } \\
\left(\mathrm{Ci} / \mathrm{m}^{3}\right)\end{array}$} & $3 E-07$ & $5 \mathrm{E}-12$ & $4 \mathrm{E}-12$ & $2 \mathrm{E}-12$ & $2 \mathrm{E}-12$ & $8 E-11$ \\
\hline
\end{tabular}

NOTES: ${ }^{a}$ Source of minimum detectability: Subsection 4.1.5 (Table 4).

Raise flow rate $=30 \mathrm{~m}^{3} / \mathrm{s}$ (Subsection 4.1.1). 


\section{CONCLUSIONS}

This report may be affected by technical product input information that requires confirmation. Any changes to the report that may occur as a result of completing the confirmation activities will be reflected in subsequent revisions. The status of the input information quality may be confirmed by review of the Document Input Reference System database. The conclusions provided in this section can only be used as preliminary information to assist future design analyses relative to efforts required for decontaminating WPs before transporting to the subsurface repository, and designing an airborne radioactivity monitoring system for detecting potential leaks from emplaced WPs.

\subsection{DERIVED LRCL}

Preliminary single-radionuclide LRCL on the external surface of WPs (Table 7) were derived for acceptance of WPs into the subsurface repository. The derivation of LRCL was based on the requirement that the airborne concentrations at the repository exhaust shall not exceed the airborne ECL. The LRCL derived for crud (Co-60) is $1,300,000 \mathrm{dpm} / 100 \mathrm{~cm}^{2}$. The most restrictive LRCL derived for alpha and beta/gamma emitters are $520 \mathrm{dpm} / 100 \mathrm{~cm}^{2}$ and $21,000 \mathrm{dpm} / 100 \mathrm{~cm}^{2}$, respectively. These most restrictive LRCL may be used to demonstrate WP suitability for emplacement in the repository. This may be accomplished in any one of a number of ways including remote surveys, by operational performance experience, or by system layout design that would inherently prevent any possible surface contamination. Remote surveys, if used, would require additional support analysis to determine the useful statistical limits on sampling frequency, detectability, bias, and error.

To demonstrate that the derived LRCL will comply with the ALARA requirements, the annual maximum doses to hypothetical individuals, both onsite and offsite, were calculated assuming that the average surface contamination on the WPs is at the LRCL shown in Table 7. The results of the calculations indicate that with surface contamination at these levels, the potential maximum doses to these hypothetical onsite and offsite individuals would be a very small fraction of the ALARA dose requirements. The maximum TEDE to offsite individual was estimated to be $0.011 \mathrm{mrem} / \mathrm{yr}$. This dose is much less than the $10 \mathrm{mrem} / \mathrm{yr}$ ALARA dose requirement for public exposure. The maximum surface and subsurface worker doses were also calculated. The maximally exposed surface and subsurface worker doses were estimated to be about $6 \%$ and $1 \%$, respectively, of the $250 \mathrm{mrem} / \mathrm{yr}$ ALARA worker dose criterion that would require a formal ALARA assessment. The collective worker dose was calculated using the number of workers estimated to be present during the emplacement period of the repository. The maximum collective worker dose was estimated to be less than $8 \%$ of the 1 person-rem/yr dose criterion that would require a formal ALARA assessment.

\subsection{POTENTIAL WP LEAK AND ITS DETECTABILITY}

Potential radioactive releases from a defective WP were evaluated based on the release model described in American National Standard for Radioactive Materials - Leakage Tests on Packages for Shipment (ANSI N14.5-97 1998, Annex B). Four illustrating examples, based on design configuration of the 21-PWR WP, were used to evaluate the potential quantities of 
release, the resulting radionuclide concentrations in the ventilation raise, and their detectabilities. The evaluations indicate that the potential quantities of release from a defective WP are heavily dependent on the size of leak hole and less on the WP temperature. A leak hole size with diameter smaller than $0.00028 \mathrm{~cm}$ may be classified as leak-tight for the 21-PWR WP, according to the definition of leak-tight specified by the ANSI N14.5-97 (1998, p.1).

The results of an evaluation of radionuclide concentrations in the ventilation raise indicate that a continuous air monitoring system may be used for detecting large potential leaks from accidents involving severe WP damages. The minimum detectable leak size was estimated to be about $0.01 \mathrm{~cm}$ in diameter. It should be noted, however, that the detectability of the air sampling system for WP leaks could be complicated by interference of two other sources: (1) a potential release from WP surface contamination, which is indistinguishable from a WP leak and (2) the existence of radon and its progeny, which is expected to be present in significant amounts during the preclosure period. 
INTENTIONALLY LEFT BLANK 


\section{REFERENCES}

\subsection{DOCUMENTS CITED}

Bird, R.B.; Stewart, W.E.; and Lightfoot, E.N. 1960. Transport Phenomena. New York, New York: John Wiley \& Sons. TIC: 208957.

BSC (Bechtel SAIC Company) 2001a. Overall Ventilation System Flow Network Calculation for Site Recommendation. CAL-SVS-HV-000002 REV 00. Las Vegas, Nevada: Bechtel SAIC Company. ACC: MOL.20010821.0073.

BSC (Bechtel SAIC Company) 2001b. Site Recommendation Subsurface Layout. ANL-SFS-MG-000001 REV 00 ICN 02. Las Vegas, Nevada: Bechtel SAIC Company. ACC: MOL.20010411.0131.

BSC (Bechtel SAIC Company) 2001c. Uncanistered Spent Nuclear Fuel Disposal Container System Description Document. SDD-UDC-SE-000001 REV 01 ICN 01. Las Vegas, Nevada: Bechtel SAIC Company. ACC: MOL.20010927.0070.

CRWMS M\&O 1998. Software Qualification Report for RSAC-5 Version 5.2 the Radiological Safety Analysis Computer Program. CSCI: 30067 V5.2. DI: 30067-2003, Rev. 00. Las Vegas, Nevada: CRWMS M\&O. ACC: MOL.19990721.0325.

CRWMS M\&O 1999a. Calculations of Acute and Chronic "Chi/Q" Dispersion Estimates for a Surface Release. TDR-MGR-MM-000001 REV 00. Las Vegas, Nevada: CRWMS M\&O. ACC: MOL.20000106.0439.

CRWMS M\&O 1999b. PWR Source Term Generation and Evaluation. BBAC00000-01717-0210-00010 REV 01. Las Vegas, Nevada: CRWMS M\&O. ACC: MOL.20000113.0333.

CRWMS M\&O 2000a. Engineering Files for Site Recommendation. TDR-WHS-MD-000001 REV 00. Las Vegas, Nevada: CRWMS M\&O. ACC: MOL.20000607.0232.

CRWMS M\&O 2000b. Design Basis Event Frequency and Dose Calculation for Site Recommendation. CAL-WHS-SE-000001 REV 01. Las Vegas, Nevada: CRWMS M\&O. ACC: MOL.20000627.0214.

CRWMS M\&O 2000c. Disposal Container Handling System Description Document. SDD-DCH-SE-000001 REV 01 ICN 01. Las Vegas, Nevada: CRWMS M\&O. ACC: MOL.20000807.0080.

CRWMS M\&O 2000d. FEIS Update to Engineering File - Subsurface Repository. TDR-EBS-MD-000007 REV 00 ICN 01. Las Vegas, Nevada: CRWMS M\&O. ACC: MOL.20000612.0058. 
CRWMS M\&O 2000e. Leakpath Factors for Radionuclide Releases from Breached Confinement Barriers. Las Vegas, Nevada: CRWMS M\&O. ACC: MOL.20000901.0021.

CRWMS M\&O 2000f. Preclosure Design Basis Events Related to Waste Packages.

ANL-MGR-MD-000012 REV 00. Las Vegas, Nevada: CRWMS M\&O.

ACC: MOL.20000725.0015.

CRWMS M\&O 2000g. Retrieval Equipment and Strategy for WP on Pallet.

ANL-WES-ME-000006 REV 00. Las Vegas, Nevada: CRWMS M\&O. ACC:

MOL.20001002.0150.

CRWMS M\&O 2000h. Subsurface Radon Calculations. CAL-SSM-NU-000003 REV 00. Las Vegas, Nevada: CRWMS M\&O. ACC: MOL.20001220.0016.

CRWMS M\&O 2000i. Repository Surface Design Engineering Files Report Supplement. TDR-WHS-EV-000001 REV 00 ICN 1. Las Vegas, Nevada: CRWMS M\&O. ACC:

MOL.20000626.0025.

CRWMS M\&O 2000j. Ventilation System Radon Review. CAL-SSM-NU-000002 REV 00. Las Vegas, Nevada: CRWMS M\&O. ACC: MOL.20000510.0167.

CRWMS M\&O 2001. Technical Work Plan for Subsurface Design Section FY 01 Work Activities. TWP-MGR-MG-000001 REV 01 ADDENDUM D. Las Vegas, Nevada: CRWMS M\&O. ACC: MOL.20010417.0455.

Curry, P.M. 2001. Monitored Geologic Repository Project Description Document.

TDR-MGR-SE-000004 REV 02 ICN 02. Las Vegas, Nevada: Bechtel SAIC Company. ACC: MOL.20010628.0224.

DOE (U.S. Department of Energy) 1994. Analysis of Experimental Data. Volume 1 of Airborne Release Fractions/Rates and Respirable Fractions for Nonreactor Nuclear Facilities.

DOE-HDBK-3010-94. Washington, D.C.: U.S. Department of Energy. TIC: 233366.

DOE (U.S. Department of Energy) 2000. Quality Assurance Requirements and Description. DOE/RW-0333P, Rev. 10. Washington, D.C.: U.S. Department of Energy, Office of Civilian Radioactive Waste Management. ACC: $\underline{\text { MOL.20000427.0422. }}$

Kocher, D.C. 1981. Radioactive Decay Data Tables, A Handbook of Decay Data for Application to Radiation Dosimetry and Radiological Assessments. DOE/TIC-11026. Washington, D.C.: U.S. Department of Energy. TIC: 228074.

NRC (U.S. Nuclear Regulatory Commission) 2000. Standard Review Plan for Spent Fuel Dry Storage Facilities. NUREG-1567. Washington, D.C.: U.S. Nuclear Regulatory Commission. TIC: 247929 . 
Perry, R.H.; Green, D.W.; and Maloney, J.O., eds. 1984. Perry's Chemical Engineers' Handbook. 6th Edition. New York, New York: McGraw-Hill. TIC: 246473.

Regulatory Guide 4.20, Rev. 0. 1996. Constraint on Releases of Airborne Radioactive Materials to the Environment for Licensees Other Than Power Reactors. Washington, D.C.: U.S. Nuclear Regulatory Commission. Readily available.

Regulatory Guide 8.34, Rev. 0. 1992. Monitoring Criteria and Methods to Calculate Occupational Radiation Doses. Washington, D.C.: U.S. Nuclear Regulatory Commission. Readily available.

\subsection{CODES, STANDARDS, REGULATIONS}

10 CFR 20. Energy: Standards for Protection Against Radiation. Readily available.

49 CFR 173. Transportation: Shippers-General Requirements for Shipments and Packagings. Readily available.

66 FR 55732. Disposal of High-Level Radioactive Wastes in a Proposed Geologic Repository at Yucca Mountain, NV. Final Rule 10 CFR Part 63. Readily available.

ANSI N14.5-97. 1998. American National Standard for Radioactive Materials - Leakage Tests on Packages for Shipment. New York, New York: American Nuclear Standards Institute.

TIC: 247029 .

ANSI N42.18-1980. 1985. Specification and Performance of On-Site Instrumentation for Continuously Monitoring Radioactivity in Effluents. New York, New York: Institute of Electrical and Electronics Engineers. TIC: 205004.

\subsection{PROCEDURES}

AP-2.21Q, Rev. 1, ICN 0, BSCN 001. Quality Determinations and Planning for Scientific, Engineering, and Regulatory Compliance Activities. Washington, D.C.: U.S. Department of Energy, Office of Civilian Radioactive Waste Management. ACC: MOL.20010212.0018.

AP-3.11Q, Rev. 2, ICN 0. Technical Reports. Washington, D.C.: U.S. Department of Energy, Office of Civilian Radioactive Waste Management. ACC: MOL.20010405.0010.

AP-3.15Q, Rev. 3, ICN 0. Managing Technical Product Inputs. Washington, D.C.: U.S. Department of Energy, Office of Civilian Radioactive Waste Management. ACC: MOL.20010801.0318.

AP-3.4Q, Rev. 2, ICN 2. Level 3 Change Control. Washington, D.C.: U.S. Department of Energy, Office of Civilian Radioactive Waste Management. ACC: MOL.20010927.0066.

AP-SI.1Q, Rev. 3, ICN 2, ECN 1. Software Management. Washington, D.C.: U.S. Department of Energy, Office of Civilian Radioactive Waste Management. ACC: MOL.20011030.0598. 
AP-SV.1Q, Rev. 0, ICN 2. Control of the Electronic Management of Information. Washington, D.C.: U.S. Department of Energy, Office of Civilian Radioactive Waste Management. ACC: MOL.20000831.0065. 
INTENTIONALLY LEFT BLANK 


\section{APPENDIX A}

\section{CALCULATION OF AVERAGE 21-PWR WP SOURCE TERMS}


INTENTIONALLY LEFT BLANK 


\section{APPENDIX A - CALCULATION OF AVERAGE 21-PWR SOURCE TERMS}

The average fuel source terms (fission gases, volatiles, and fuel particulates) are taken from $P W R$ Source Term Generation and Evaluation (CRWMS M\&O 1999b, Attachment X), based on PWR fuel with $4 \%$ initial enrichment, $48 \mathrm{GWd}$ /MTU burnup, and $25 \mathrm{yr}$ decay period (CRWMS M\&O 1999 b, p. 24). Table A-1 lists the radionuclide source terms and their totals in the average PWR spent fuel assembly and the 21-PWR WP. 
Table A.1. Average 21-PWR WP Source Terms

\begin{tabular}{|c|c|c|c|c|c|}
\hline Nuclide & $\begin{array}{c}\text { Avg PWR } \\
\text { Curies/ } \\
\text { Assembly }\end{array}$ & $\begin{array}{l}\text { Avg PWR } \\
\text { Curies } \text { PWP }^{\mathrm{b}}\end{array}$ & Nuclide & $\begin{array}{c}\text { Avg PWR } \\
\text { Curies/ } \\
\text { Assembly }\end{array}$ & $\begin{array}{l}\text { Avg PWR }{ }^{b} \\
\text { Curies/WP }\end{array}$ \\
\hline Gases & & & $\begin{array}{l}\text { Fuel fines } \\
\text { (continued) }\end{array}$ & & \\
\hline $\mathrm{H}-3$ & $1.14 \mathrm{E}+02$ & $2.39 \mathrm{E}+03$ & Eu-155 & $5.15 E+01$ & $1.08 E+03$ \\
\hline C-14 & 3.32E-01 & $6.97 \mathrm{E}+00$ & $\mathrm{Fe}-55$ & $3.46 E+00$ & $7.27 E+01$ \\
\hline $\mathrm{Kr}-85$ & $1.13 E+03$ & $2.37 E+04$ & $\mathrm{Nb}-93 \mathrm{~m}$ & $1.30 \mathrm{E}+01$ & $2.73 E+02$ \\
\hline l-129 & 2.19E-02 & 4.60E-01 & $\mathrm{Nb}-94$ & $8.39 E-01$ & $1.76 \mathrm{E}+01$ \\
\hline \multirow[t]{2}{*}{ Total Gases } & $1.24 \mathrm{E}+03$ & $2.61 E+04$ & $\mathrm{Ni}-59$ & $2.09 E+00$ & 4.39E+01 \\
\hline & & & $\mathrm{Ni}-63$ & $2.52 \mathrm{E}+02$ & $5.29 \mathrm{E}+03$ \\
\hline Volatiles & & & $\mathrm{Np}-237$ & 2.47E-01 & $5.19 \mathrm{E}+00$ \\
\hline Cs-134 & $2.52 E+01$ & $5.29 E+02$ & $\mathrm{~Pa}-231$ & 2.97E-05 & $6.24 \mathrm{E}-04$ \\
\hline Cs-135 & $3.50 E-01$ & $7.35 \mathrm{E}+00$ & $\mathrm{Pd}-107$ & 8.41E-02 & $1.77 \mathrm{E}+00$ \\
\hline Cs- 137 & $4.11 \mathrm{E}+04$ & $8.63 E+05$ & $\mathrm{Pm}-147$ & 1.19E+02 & $2.50 E+03$ \\
\hline Sr-90 & $2.72 \mathrm{E}+04$ & $5.71 E+05$ & Pu-238 & $2.29 E+03$ & $4.81 E+04$ \\
\hline $\mathrm{Ru}-106$ & 1.23E-02 & $2.58 \mathrm{E}-01$ & Pu-239 & 1.77E+02 & $3.72 E+03$ \\
\hline \multirow[t]{2}{*}{ Total Volatiles } & $6.83 E+04$ & $1.43 E+06$ & Pu-240 & $3.18 E+02$ & $6.68 \mathrm{E}+03$ \\
\hline & & & Pu-241 & $2.46 \mathrm{E}+04$ & $5.17 E+05$ \\
\hline Fuel fines & & & Pu-242 & $1.64 E+00$ & $3.44 E+01$ \\
\hline Ac-227 & 1.61E-05 & $3.38 \mathrm{E}-04$ & Sb-125 & $9.71 E+00$ & $2.04 E+02$ \\
\hline$A m-241$ & $1.98 \mathrm{E}+03$ & $4.16 \mathrm{E}+04$ & $\mathrm{Se}-79$ & 4.57E-02 & $9.60 \mathrm{E}-01$ \\
\hline$A m-242 m$ & $6.39 \mathrm{E}+00$ & $1.34 E+02$ & Sm-151 & $2.11 E+02$ & $4.43 E+03$ \\
\hline$A m-243$ & $2.20 \mathrm{E}+01$ & $4.62 E+02$ & Sn-126 & $3.85 E-01$ & $8.09 E+00$ \\
\hline Cd-113m & $7.66 \mathrm{E}+00$ & $1.61 \mathrm{E}+02$ & Tc-99 & $8.98 E+00$ & $1.89 E+02$ \\
\hline $\mathrm{Cl}-36$ & $6.80 E-03$ & 1.43E-01 & Th-230 & $1.48 E-04$ & $3.11 \mathrm{E}-03$ \\
\hline $\mathrm{Cm}-242$ & $5.26 \mathrm{E}+00$ & $1.10 E+02$ & $\mathrm{U}-232$ & 2.04E-02 & $4.28 \mathrm{E}-01$ \\
\hline $\mathrm{Cm}-243$ & $1.03 E+01$ & $2.16 \mathrm{E}+02$ & $\mathrm{U}-233$ & $3.79 \mathrm{E}-05$ & 7.96E-04 \\
\hline $\mathrm{Cm}-244$ & $1.36 \mathrm{E}+03$ & $2.86 E+04$ & $\mathrm{U}-234$ & $6.77 \mathrm{E}-01$ & $1.42 E+01$ \\
\hline $\mathrm{Cm}-245$ & 3.07E-01 & $6.45 E+00$ & $U-235$ & 7.37E-03 & $1.55 \mathrm{E}-01$ \\
\hline $\mathrm{Cm}-246$ & $1.04 E-01$ & $2.18 \mathrm{E}+00$ & U-236 & $1.72 \mathrm{E}-01$ & $3.61 E+00$ \\
\hline Co-60 & $3.13 E+02$ & $6.57 \mathrm{E}+03$ & $\mathrm{U}-238$ & $1.48 \mathrm{E}-01$ & $3.11 \mathrm{E}+00$ \\
\hline \multirow[t]{2}{*}{ Eu-154 } & $6.71 E+02$ & $1.41 E+04$ & $Z r-93$ & 8.94E-01 & $1.88 \mathrm{E}+01$ \\
\hline & & & Total Fines & $3.24 E+04$ & $6.81 E+05$ \\
\hline
\end{tabular}

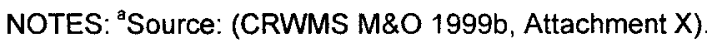

${ }^{\mathrm{b}}$ Average Curies per WP $=$ Average Curies per Assembly $\times 21$ Assembly 
INTENTIONALLY LEFT BLANK 
APPENDIX B

DETERMINATION OF WP LEAK-TIGHT HOLE DIAMETER 
INTENTIONALLY LEFT BLANK 


\section{APPENDIX B - DETERMINATION OF WP LEAK-TIGHT HOLE DIAMETER}

The determination of the WP leak-tight hole diameter is based on the ANSI N14.5-97 (1998) definition of leak-tight (ANSI N14.5-97 1998, p. 1). Leak-tight is defined in ANSI N14.5-97 (1998) as

"a degree of package containment that in a practical sense precludes any significant release of radioactive materials. This degree of containment is achieved by demonstration of a leakage rate less than or equal to $1 \times 10^{-7} \mathrm{ref} . \mathrm{cm}^{3} / \mathrm{s}$, of air at an upstream pressure of 1 atmosphere (atm) absolute (abs) and a downstream pressure of 0.01 atm abs or less."

In this appendix the reference air leakage rates for a range of leak hole diameters are calculated first to determine the WP leak-tight hole diameter. The leak-tight hole diameter is then used to calculate two sets of WP air leakage rate for pressure conditions other than the referenced condition defined above for comparison.

The equations used to calculate the volume leakage rate from a WP are equations 9,10 and 11 as described in Subsection 3.2:

$$
\begin{gathered}
L=\left(F_{c}+F_{m}\right)\left(P_{u}-P_{d}\right) P_{a} / P_{u} \\
F_{c}=\frac{2.49 \times 10^{6} D^{4}}{\alpha \mu} \\
F_{m}=\frac{3.81 \times 10^{3} D^{3} \sqrt{T / M}}{\alpha P_{a}}
\end{gathered}
$$

where

$$
\begin{aligned}
& \alpha=\text { leakage hole length, } \mathrm{cm} \\
& \mu=\text { viscosity, } \mathrm{cP} \\
& D=\text { leakage hole diameter, } \mathrm{cm} \\
& \mathrm{T}=\text { standard temperature, } 298 \mathrm{~K} \\
& \mathrm{M}=\text { molecular weight, grams per mole } \\
& \mathrm{P}_{\mathrm{a}}=\text { average stream pressure }=0.5\left(\mathrm{P}_{\mathrm{u}}+\mathrm{P}_{\mathrm{d}}\right), \text { atm abs } \\
& \mathrm{P}_{\mathrm{u}}=\text { fluid upstream pressure, atm abs } \\
& \mathrm{P}_{\mathrm{d}}=\text { fluid downstream pressure, } \mathrm{atm} \text { abs } \\
& \mathrm{L}=\text { volumetric leakage rate, } \mathrm{cm}^{3} / \mathrm{s} \\
& \mathrm{F}_{\mathrm{c}}=\text { coefficient of continuum flow conductance per unit pressure, } \mathrm{cm}^{3} / \mathrm{atm}-\mathrm{s} \\
& \mathrm{F}_{\mathrm{m}}=\text { coefficient of free molecular flow conductance per unit pressure, } \mathrm{cm}^{3} / \mathrm{atm}-\mathrm{s}
\end{aligned}
$$

Table B-1 below summarizes the input parameters used for leakage rate calculations. The actual leakage rate calculations using equations B-1, B-2 and B-3 for various leakage hole diameters are provided in Table B-2. 
Table B-1. Leak-tight Calculation Parameters

\begin{tabular}{|l|c|c|c|}
\hline \multicolumn{1}{|c|}{ Parameter } & Symbol & Value & Source Section \\
\hline Gas medium & N/A & air & App. B, p. B-1 \\
\hline Viscosity of air at $298 \mathrm{~K}(\mathrm{cP})$ & $\mu$ & $1.85 \mathrm{E}-02$ & Subsection 4.1.4 \\
\hline Pressure upstream (atm) & $\mathrm{Pu}_{\mathrm{u}}$ & $1.00 \mathrm{E}+00$ & App. B, p. B-1 \\
\hline Pressure downstream (atm) & $\mathrm{P}_{\mathrm{d}}$ & $1.00 \mathrm{E}-02$ & App. B, p. B-1 \\
\hline Average pressure $(\mathrm{atm})$ & $\mathrm{Pa}_{\mathrm{a}}$ & $5.05 \mathrm{E}-01$ & $0.5\left(\mathrm{Pu}_{\mathrm{u}}+\mathrm{P}_{\mathrm{d}}\right)$ \\
\hline Standard Temperature $(\mathrm{K})$ & $\mathrm{T}$ & $2.98 \mathrm{E}+02$ & App. B, p. B-1 \\
\hline Air Molecular weight $(\mathrm{gmol})$ & $\mathrm{M}$ & $2.90 \mathrm{E}+01$ & Subsection 4.1.4 \\
\hline leakage hole length, $\mathrm{cm}$ & $\alpha$ & $7.00 \mathrm{E}+00$ & Subsection 4.2.11 \\
\hline WP Void volume $\left(\mathrm{cm}^{3}\right)$ & $\mathrm{V}$ & $4.38 \mathrm{E}+06$ & Subsection 4.1.2 \\
\hline
\end{tabular}

Table B-2. Leakage Rate Calculations to Determine Leak-tight Hole Diameter

\begin{tabular}{|c|c|c|c|}
\hline \multicolumn{4}{|c|}{ Note: Leak-tight is defined as leakage rate $<1.0 \mathrm{E}-7\left(\mathrm{~cm}^{3} / \mathrm{s}\right)(\mathrm{p} . \mathrm{B}-1)$} \\
\hline $\begin{array}{c}\text { D } \\
\text { Leak Hole Diameter }(\mathbf{c m})\end{array}$ & $\mathrm{F}_{\mathrm{c}}$ (Eq. B-1) & $F_{m}$ (Eq. B-2) & $\begin{array}{c}\text { L (Eq. B-3) } \\
\text { Leakage Rate }\left(\mathrm{cm}^{3} / \mathrm{s}\right)\end{array}$ \\
\hline $1.00 \mathrm{E}-05$ & $1.92 \mathrm{E}-13$ & $3.45 \mathrm{E}-12$ & $1.82 \mathrm{E}-12$ \\
\hline $1.00 \mathrm{E}-04$ & $1.92 \mathrm{E}-09$ & $3.45 \mathrm{E}-09$ & $2.69 \mathrm{E}-09$ \\
\hline $\mathbf{2 . 8 2 E}-04$ & $1.22 \mathrm{E}-07$ & $7.75 \mathrm{E}-08$ & $9.95 \mathrm{E}-08$ \\
\hline $1.00 \mathrm{E}-03$ & $1.92 \mathrm{E}-05$ & $3.45 \mathrm{E}-06$ & $1.13 \mathrm{E}-05$ \\
\hline $1.00 \mathrm{E}-02$ & $1.92 \mathrm{E}-01$ & $3.45 \mathrm{E}-03$ & $9.79 \mathrm{E}-02$ \\
\hline $1.00 \mathrm{E}-01$ & $1.92 \mathrm{E}+03$ & $3.45 \mathrm{E}+00$ & $9.63 \mathrm{E}+02$ \\
\hline
\end{tabular}

Verification Calculations:

$$
\begin{aligned}
& \text { Verification calculations using } D=2.82 \mathrm{E}-04 \mathrm{~cm} \\
& F_{c}=2.49 E 6 \times(2.82 E-4)^{4} /(7 \times 1.85 E-2)=1.216 E-7 \\
& F_{m}=3.81 E 3 \times(2.82 E-4)^{3} \times(298 / 29)^{0.5} /(7 \times 0.505)=7.75 E-8 \\
& L=(1.216 E-7+7.75 E-8) \times(1-0.01) \times 0.505 / 1=9.95 E-8
\end{aligned}
$$

Based on the definition of leak-tight and the results of the leakage rate calculations, it can be determined that for a 21-PWR WP any leak hole sizes with diameters less than $0.00028 \mathrm{~cm}$ may be classified as leak-tight. 
The WP leak-tight air leakage rates for upstream pressure of 2 and 3 atm and downstream pressure of $1 \mathrm{~atm}$ are calculated below for comparison with the reference leak-tight air leakage rate of $1.0 \mathrm{E}-07 \mathrm{~cm}^{3} / \mathrm{s}$.

The leak-tight air leakage rates are calculated using the leak-tight hole diameter of $0.00028 \mathrm{~cm}$ determined above and equations B-1, B-2 and B-3. The calculations are provided in Table B-3.

Table B-3. Leak-tight Leakage Rate Calculations

\begin{tabular}{|c|c|c|c|c|}
\hline \multicolumn{5}{|c|}{ Note: leak-tight hole diameter $=0.00028 \mathrm{~cm}$} \\
\hline $\begin{array}{c}\mathbf{P}_{\mathbf{u}} \\
(\mathbf{a t m})\end{array}$ & $\begin{array}{c}\mathbf{P}_{\mathbf{d}} \\
(\mathbf{a t m})\end{array}$ & $\mathbf{F}_{\mathrm{c}}$ (Eq. B-1) & $\mathbf{F}_{\mathrm{m}}$ (Eq. B-2) & $\begin{array}{c}\text { L (Eq. B-3) } \\
\text { Leakage Rate }\left(\mathrm{cm}^{3} / \mathbf{s}\right)\end{array}$ \\
\hline 2 & 1 & $1.18 \mathrm{E}-07$ & $2.55 \mathrm{E}-08$ & $1.08 \mathrm{E}-07$ \\
\hline 3 & 1 & $1.18 \mathrm{E}-07$ & $1.92 \mathrm{E}-08$ & $1.83 \mathrm{E}-07$ \\
\hline
\end{tabular}

Verification Calculations:

Verification calculations using $\mathrm{Pu}=3 \mathrm{~atm}$

$F_{c}=2.49 E 6 \times(2.8 \mathrm{E}-4)^{4} /(7 \times 1.85 \mathrm{E}-2)=1.182 \mathrm{E}-7$

$P_{a}=0.5 \times(3+1)=2$

$F_{m}=3.81 E 3 \times(2.8 E-4)^{3} \times(298 / 29)^{0.5} /(7 \times 2)=1.915 E-8$

$\mathrm{L}=(1.182 \mathrm{E}-7+1.915 \mathrm{E}-8) \times(3-1) \times 2 / 3=1.831 \mathrm{E}-7$ 


\section{INTENTIONALLY LEFT BLANK}




\section{APPENDIX C}

CALCULATION OF WP INTERNAL PRESSURE 
INTENTIONALLY LEFT BLANK 


\section{APPENDIX C - CALCULATION OF WP INTERNAL PRESSURE}

The calculation of the internal pressure in the 21-PWR WP is based on the approach described in Preclosure Design Basis Events Related to Waste Packages (CRWMS M\&O 2000f, Attachment III).

The internal pressure $\mathrm{P}$ in the WP is calculated according to the ideal gas law:

$$
\mathrm{P}=\mathrm{nRT} / \mathrm{V}
$$

where

$$
\begin{aligned}
& \mathrm{n}=\text { the number of helium moles in the WP } \\
& \mathrm{R}=\text { gas constant } \\
& \mathrm{T}=\text { the WP inside temperature } \\
& \mathrm{V}=\text { the WP void volume }
\end{aligned}
$$

Table C-1 below summarizes the input parameters used for pressure calculation. As indicated in Preclosure Design Basis Events Related to Waste Packages (CRWMS M\&O 2000f, p. III-3 and p. III-4), the number of helium gas moles listed in Table C-1 are conservative values and would lead to overestimating the pressure in the WP.

The internal pressure calculations using equation $\mathrm{C}-1$ for various fuel rod failure rates are provided in Table C-2.

Table C-1. Summary of Design Parameters for Appendix C

\begin{tabular}{|l|c|}
\hline \multicolumn{1}{|c|}{ Parameter } & Value $^{\mathrm{a}}$ \\
\hline Number of assembly per WP & 21 \\
\hline PWR number of rods per assembly & 208 \\
\hline & \\
\hline WP void volume & $4.38 \mathrm{~m}^{3}$ \\
\hline PWR fuel rod void volume & $35 \mathrm{~cm}^{3}$ \\
\hline Initial helium gas moles in WP void & 179.1 \\
\hline Initial helium gas moles in fuel rod & 0.117 \\
\hline & \\
\hline Gas law constant & $8.3144 \mathrm{~J} \mathrm{~mol}^{-1} \mathrm{~K}^{-1}$ \\
\hline NOTES:
\end{tabular}


Table C-2. Calculation Sheet for WP Internal Pressure

\begin{tabular}{|c|c|c|c|c|c|}
\hline$\%$ Fuel failed, 'F & $100 \%$ & $50 \%$ & $25 \%$ & $10 \%$ & $3 \%$ \\
\hline (1) Void VOL $\left(\mathrm{m}^{3}\right), \mathrm{V}$ & $4.53 E+00$ & $4.46 \mathrm{E}+00$ & $4.42 E+00$ & $4.40 E+00$ & $4.38 \mathrm{E}+00$ \\
\hline (2) Final Gas Moles, $n$ & $6.91 E+02$ & $4.35 \mathrm{E}+02$ & $3.07 E+02$ & $2.30 E+02$ & $1.94 E+02$ \\
\hline Temperature $\left({ }^{\circ} \mathrm{C}\right), \mathrm{T}$ & \multicolumn{5}{|c|}{ (3) Pressure, P (Pascal) } \\
\hline 25 & $3.78 \mathrm{E}+05$ & $2.42 E+05$ & $1.72 E+05$ & $1.30 E+05$ & $1.10 E+05$ \\
\hline 50 & 4.10E+05 & $2.62 E+05$ & $1.87 E+05$ & $1.41 E+05$ & $1.19 E+05$ \\
\hline 100 & $4.73 E+05$ & $3.03 E+05$ & $2.16 E+05$ & $1.63 E+05$ & $1.38 \mathrm{E}+05$ \\
\hline 200 & $6.00 E+05$ & $3.84 \mathrm{E}+05$ & $2.73 E+05$ & $2.06 \mathrm{E}+05$ & $1.74 \mathrm{E}+05$ \\
\hline 300 & $7.27 E+05$ & $4.65 E+05$ & $3.31 E+05$ & $2.50 E+05$ & $2.11 \mathrm{E}+05$ \\
\hline 350 & $7.90 E+05$ & $5.06 \mathrm{E}+05$ & $3.60 E+05$ & $2.71 \mathrm{E}+05$ & $2.30 E+05$ \\
\hline 400 & $8.53 E+05$ & $5.46 E+05$ & $3.89 E+05$ & $2.93 E+05$ & $2.48 \mathrm{E}+05$ \\
\hline 500 & $9.80 E+05$ & $6.28 E+05$ & $4.47 E+05$ & $3.37 E+05$ & $2.85 \mathrm{E}+05$ \\
\hline 570 & $1.07 E+06$ & $6.84 E+05$ & $4.87 E+05$ & $3.67 E+05$ & $3.11 E+0.5$ \\
\hline 600 & $1.11 E+06$ & $7.09 E+05$ & $5.05 E+05$ & $3.80 E+05$ & $3.22 \mathrm{E}+05$ \\
\hline
\end{tabular}

NOTES: (1) $V=4.38\left(\mathrm{~m}^{3}\right)+0.000035\left(\mathrm{~m}^{3}\right) \times 208$ (rods/assy) $\times 21$ (assy/WP) $\times \mathrm{F}$.

(2) $n=179.1$ (moles) +0.117 (moles/rod) $\times 208$ (rods/assy) $\times 21$ (assyMP) $\times F$.

(3) $P=n(m o l) \times 8.3144\left(\mathrm{~J} \mathrm{~mol}^{-1} \mathrm{~K}^{-1}\right) \times(273+\mathrm{T})(\mathrm{K}) / \mathrm{V}\left(\mathrm{m}^{3}\right)$.

Verification Calculations:

Verification calculations using $\mathrm{F}=3 \%, \mathrm{~T}=300{ }^{\circ} \mathrm{C}$

(1) $V=4.38+0.000035 \times 208 \times 21 \times 0.03=4.3846$

(2) $n=179.1+0.117 \times 208 \times 21 \times 0.03=194.43$

(3) $P=194.43 \times 8.3144 \times(273+300) / 4.3846=211263$ 
INTENTIONALLY LEFT BLANK 
APPENDIX D

CALCULATION OF 21-PWR WP LEAKAGE RATE 
INTENTIONALLY LEFT BLANK 


\section{APPENDIX D - CALCULATION OF 21-PWR WP LEAKAGE RATE}

The equations used to calculate the volume leakage rate from a WP are equations 9,10 , and 11 as described in Subsection 3.2:

$$
\begin{gathered}
\mathrm{L}=\left(\mathrm{F}_{\mathrm{c}}+\mathrm{F}_{\mathrm{m}}\right)\left(\mathrm{P}_{\mathrm{u}}-\mathrm{P}_{\mathrm{d}}\right) \mathrm{P}_{\mathrm{a}} / \mathrm{P}_{\mathrm{u}} \\
\mathrm{F}_{\mathrm{c}}=\frac{2.49 \times 10^{6} \mathrm{D}^{4}}{\alpha \mu} \\
\mathrm{F}_{\mathrm{m}}=\frac{3.81 \times 10^{3} \mathrm{D}^{3} \sqrt{\mathrm{T} / \mathrm{M}}}{\alpha \mathrm{P}_{\mathrm{a}}}
\end{gathered}
$$

where

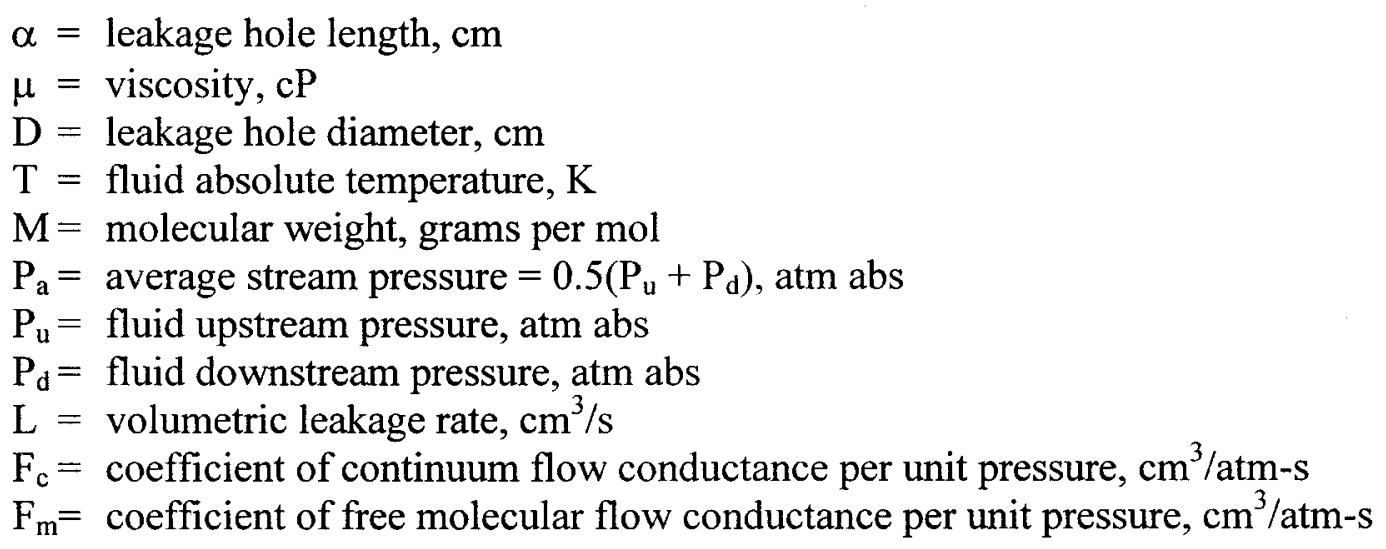

Table D-1 summarizes the input parameters used for leakage rate calculations. The leakage rate calculations using the above equations for various WP temperatures and leakage hole diameters are provided in Table D-2. Table D-3 presents the WP release source term calculations. The calculation of WP radioactive source term releases is provided in Table D-4. 
Table D-1. WP Leakage Rates Calculation Parameters

Note: $3 \%$ Fuel rod Failed Case (Assumption 4.2.16)

\begin{tabular}{|c|c|c|c|c|}
\hline Inputs & & \multicolumn{3}{|c|}{ WP Temperature $\left({ }^{\circ} \mathrm{C}\right)$} \\
\hline Parameter & Symbol & $300 \mathrm{C}$ & $350 \mathrm{C}$ & $500 \mathrm{C}$ \\
\hline Viscosity $(\mathrm{cP})^{(\mathrm{a})}$ & $\mu$ & $3.00 \mathrm{E}-02$ & $3.20 \mathrm{E}-02$ & $3.80 \mathrm{E}-02$ \\
\hline Pressure upstream $\left(\mathrm{P}_{\mathrm{a}}\right)^{(\mathrm{b})}$ & $P_{u}$ & $2.11 \mathrm{E}+05$ & $2.30 E+05$ & $2.85 \mathrm{E}+05$ \\
\hline Pressure upstream (atm) ${ }^{(\mathrm{c})}$ & $P_{u}$ & $2.09 E+00$ & $2.27 E+00$ & $2.81 E+00$ \\
\hline Pressure downstream (atm) ${ }^{(\mathrm{d})}$ & $P_{d}$ & $8.78 E-01$ & 8.78E-01 & $8.78 \mathrm{E}-01$ \\
\hline Average pressure (atm) ${ }^{(e)}$ & $\mathrm{Pa}$ & $1.48 \mathrm{E}+00$ & $1.57 \mathrm{E}+00$ & $1.85 \mathrm{E}+00$ \\
\hline Temperature $(\mathrm{K})^{(f)}$ & $T$ & $5.73 E+02$ & $6.23 E+02$ & $7.73 E+02$ \\
\hline Helium molecular weight $(\mathrm{gmol}){ }^{(\mathrm{g})}$ & $M$ & $4.00 \mathrm{E}+00$ & $4.00 \mathrm{E}+00$ & $4.00 \mathrm{E}+00$ \\
\hline Path length $(\mathrm{cm})^{(\mathrm{h})}$ & $\alpha$ & $7.00 \mathrm{E}+00$ & $7.00 \mathrm{E}+00$ & $7.00 \mathrm{E}+00$ \\
\hline WP void volume $\left(\mathrm{cm}^{3}\right)^{(1)}$ & V & $4.38 E+06$ & $4.38 \mathrm{E}+06$ & $4.38 \mathrm{E}+06$ \\
\hline
\end{tabular}

NOTES: ${ }^{(\text {a) }}$ Source: Table 3 , Subsection 4.14
(b) Source: Table C-2
(c) $\mathrm{P}_{\mathrm{u}}(\mathrm{atm})=\mathrm{P}_{\mathrm{u}}\left(\mathrm{P}_{\mathrm{a}}\right) / 1.01 \mathrm{E} 5\left(\mathrm{P}_{\mathrm{a}} / \mathrm{atm}\right)$ (Subsection 4.1.6)
(d) Source: Subsection 4.2.20
(e) $\mathrm{P}_{\mathrm{a}}=0.5\left(\mathrm{P}_{\mathrm{u}}+\mathrm{P}_{\mathrm{d}}\right)$
(f) $T(K)=273+T(C)$
(g) Source: Table 2, Subsection 4.1.3
(h) Source: Subsection 4.2.11
(i) Source: Subsection 4.1.2 
Table D-2. Calculation Sheet for WP Volumetric Leakage Rate

\begin{tabular}{|c|c|c|c|c|}
\hline $\begin{array}{c}\text { WP } \\
\text { Internal } \\
\text { Temperature } \\
\left({ }^{\circ} \mathrm{C}\right)\end{array}$ & $\begin{array}{c}\text { Leak Hole } \\
\text { Diameter }(\mathrm{cm})\end{array}$ & $\begin{array}{c}(1) \\
F_{c}(\text { Eq. D-1) }\end{array}$ & $\stackrel{(2)}{F_{m}(E q . D-2)}$ & $\begin{array}{c}(3) \\
\text { L (Eq. D-3) } \\
\text { Leakage Rate } \\
\left(\mathrm{cm}^{3} / \mathrm{s}\right)\end{array}$ \\
\hline \multirow{5}{*}{300} & $1.00 \mathrm{E}-05$ & $1.19 \mathrm{E}-13$ & $4.40 \mathrm{E}-12$ & $3.87 E-12$ \\
\hline & $1.00 \mathrm{E}-04$ & 1.19E-09 & $4.40 \mathrm{E}-09$ & 4.79E-09 \\
\hline & 1.00E-03 & 1.19E-05 & $4.40 \mathrm{E}-06$ & $1.39 \mathrm{E}-05$ \\
\hline & $1.00 \mathrm{E}-02$ & $1.19 \mathrm{E}-01$ & $4.40 \mathrm{E}-03$ & 1.05E-01 \\
\hline & $1.00 \mathrm{E}-01$ & $1.19 E+03$ & $4.40 E+00$ & $1.02 \mathrm{E}+03$ \\
\hline \multirow{5}{*}{350} & $1.00 \mathrm{E}-05$ & $1.11 \mathrm{E}-13$ & $4.32 E-12$ & 4.27E-12 \\
\hline & 1.00E-04 & 1.11E-09 & 4.32E-09 & 5.23E-09 \\
\hline & $1.00 \mathrm{E}-03$ & 1.11E-05 & $4.32 E-06$ & $1.49 \mathrm{E}-05$ \\
\hline & $1.00 \mathrm{E}-02$ & $1.11 \mathrm{E}-01$ & 4.32E-03 & 1.11E-01 \\
\hline & $1.00 \mathrm{E}-01$ & $1.11 \mathrm{E}+03$ & $4.32 \mathrm{E}+00$ & $1.08 \mathrm{E}+03$ \\
\hline \multirow{5}{*}{500} & $1.00 \mathrm{E}-05$ & $9.36 \mathrm{E}-14$ & $4.10 \mathrm{E}-12$ & 5.32E-12 \\
\hline & $1.00 \mathrm{E}-04$ & $9.36 \mathrm{E}-10$ & 4.10E-09 & 6.39E-09 \\
\hline & $1.00 \mathrm{E}-03$ & 9.36E-06 & 4.10E-06 & 1.71E-05 \\
\hline & $1.00 \mathrm{E}-02$ & $9.36 \mathrm{E}-02$ & 4.10E-03 & 1.24E-01 \\
\hline & $1.00 \mathrm{E}-01$ & $9.36 \mathrm{E}+02$ & $4.10 E+00$ & $1.19 \mathrm{E}+03$ \\
\hline
\end{tabular}

NOTES: (1) Calculated based on Eq. D-2 and parameters listed in Table D-1.

(2) Calculated based on Eq. D-3 and parameters listed in Table D-1.

(3) Calculated based on Eq. D-1, values of (1) \& (2) and $P_{u}$ \& $P_{d}$ listed in Table D-1.

Verification Calculations:

Verification calculations using $D=1.00 \mathrm{E}-03 \mathrm{~cm}, \mathrm{~T}=350^{\circ} \mathrm{C}$

$$
\begin{aligned}
& F_{c}=2.49 E 6 \times(1.0 E-3)^{4} /(7 \times 3.2 E-2)=1.1116 E-5 \\
& F_{m}=3.81 E 3 \times(1.0 E-3)^{3} \times(623 / 4)^{0.5} /(7 \times 1.5742)=4.7549 E-5 / 11.0=4.32 E-6 \\
& L=(1.1116 E-5+4.32 E-6) \times(2.27-0.8783) \times 1.5742 / 2.27=1.49 E-5
\end{aligned}
$$


Table D-3. WP Source Term Calculation Sheet

\begin{tabular}{|c|c|c|c|c|}
\hline Nuclide & $\begin{array}{c}\text { (1) } \\
\text { Ci per WP }\end{array}$ & $\begin{array}{c}\text { Failed Activity } \\
\text { (Ci) }\end{array}$ & $\begin{array}{c}\text { (3) } \\
\text { Gap Release } \\
\text { Fraction }\end{array}$ & $\begin{array}{c}\text { (4) } \\
\text { Gap Activity } \\
\text { (Ci) }\end{array}$ \\
\hline Gases & $2.61 \mathrm{E}+04$ & $7.84 \mathrm{E}+02$ & $3.00 \mathrm{E}-01$ & $2.35 \mathrm{E}+02$ \\
\hline Volatiles & $1.43 \mathrm{E}+06$ & $4.30 \mathrm{E}+04$ & $2.00 \mathrm{E}-04$ & $8.61 \mathrm{E}+00$ \\
\hline Fines & $6.81 \mathrm{E}+05$ & $2.04 \mathrm{E}+04$ & $3.00 \mathrm{E}-05$ & $6.13 \mathrm{E}-01$ \\
\hline Crud & $4.93 \mathrm{E}+01$ & $4.93 \mathrm{E}+01$ & $1.50 \mathrm{E}-01$ & $7.39 \mathrm{E}+00$ \\
\hline Total Activity & $2.14 \mathrm{E}+06$ & $6.43 \mathrm{E}+04$ & N/A & $2.52 \mathrm{E}+02$ \\
\hline
\end{tabular}

NOTES:(1) Source: Table 5, Subsection 4.2.16.

(2) (1) $\times 3 \%$ fuel rod failed (for Gases, Volatiles and Fines; Assumption 4.2.17). For Crud: (1) $\times 100 \%$.

(3) Source: Table 6, Subsection 4.2.17.

(4) (2) $\times(3)$. 
Table D-4. WP Leakage Rate Calculation Sheet

\begin{tabular}{|c|c|c|c|c|c|c|c|}
\hline $\begin{array}{c}\text { WP } \\
\text { Internal } \\
\text { Temperature } \\
\left({ }^{\circ} \mathrm{C}\right)\end{array}$ & $\begin{array}{l}\text { Leak Hole } \\
\text { Diameter } \\
\text { (cm) }\end{array}$ & $\begin{array}{c}(1) \\
\text { Leakage } \\
\text { Rate } \\
\left(\mathrm{cm}^{3} / \mathrm{s}\right)\end{array}$ & $\begin{array}{c}\text { (2) } \\
\text { Gas Leak } \\
\text { Rate (Ci/s) }\end{array}$ & $\begin{array}{c}(3) \\
\text { Volatile } \\
\text { Leak Rate } \\
\text { (Ci/s) }\end{array}$ & $\begin{array}{c}(4) \\
\text { Fine Leak } \\
\text { Rate (Ci/s) }\end{array}$ & $\begin{array}{l}\text { (5) } \\
\text { Crud Leak } \\
\text { Rate (Ci/s) }\end{array}$ & $\begin{array}{l}\quad(6) \\
\text { Total Leak } \\
\text { Rate (Ci/s) }\end{array}$ \\
\hline \multirow{5}{*}{300} & 1.00E-05 & 3.87E-12 & $2.08 \mathrm{E}-16$ & $7.60 \mathrm{E}-19$ & $5.41 E-20$ & $6.53 E-19$ & $2.09 E-16$ \\
\hline & $1.00 \mathrm{E}-04$ & 4.79E-09 & $2.57 \mathrm{E}-13$ & $9.40 \mathrm{E}-16$ & $6.69 E-17$ & $8.08 \mathrm{E}-16$ & $2.59 \mathrm{E}-13$ \\
\hline & $1.00 \mathrm{E}-03$ & 1.39E-05 & $7.48 \mathrm{E}-10$ & $2.74 \mathrm{E}-12$ & $1.95 \mathrm{E}-13$ & $2.35 \mathrm{E}-12$ & $7.53 \mathrm{E}-10$ \\
\hline & 1.00E-02 & $1.05 \mathrm{E}-01$ & $5.66 \mathrm{E}-06$ & 2.07E-08 & 1.47E-09 & 1.78E-08 & $5.70 \mathrm{E}-06$ \\
\hline & $1.00 E-01$ & $1.02 \mathrm{E}+03$ & $5.48 E-02$ & 2.00E-04 & 1.43E-05 & $1.72 E-04$ & 5.51E-02 \\
\hline \multirow{5}{*}{350} & 1.00E-05 & 4.27E-12 & $2.29 \mathrm{E}-16$ & 8.38E-19 & $5.97 \mathrm{E}-20$ & $7.20 \mathrm{E}-19$ & $2.31 \mathrm{E}-16$ \\
\hline & $1.00 \mathrm{E}-04$ & 5.23E-09 & $2.81 \mathrm{E}-13$ & $1.03 E-15$ & $7.32 E-17$ & 8.83E-16 & $2.83 E-13$ \\
\hline & 1.00E-03 & $1.49 \mathrm{E}-05$ & $7.98 \mathrm{E}-10$ & 2.92E-12 & $2.08 E-13$ & $2.51 \mathrm{E}-12$ & 8.03E-10 \\
\hline & $1.00 \mathrm{E}-02$ & 1.11E-01 & 5.97E-06 & 2.19E-08 & $1.56 \mathrm{E}-09$ & $1.88 \mathrm{E}-08$ & 6.01E-06 \\
\hline & $1.00 \mathrm{E}-01$ & $1.08 \mathrm{E}+03$ & 5.77E-02 & 2.11E-04 & $1.50 \mathrm{E}-05$ & $1.81 E-04$ & 5.81E-02 \\
\hline \multirow{5}{*}{500} & $1.00 \mathrm{E}-05$ & $5.32 \mathrm{E}-12$ & $2.86 E-16$ & $1.05 E-18$ & $7.44 E-20$ & 8.98E-19 & $2.88 \mathrm{E}-16$ \\
\hline & $1.00 \mathrm{E}-04$ & $6.39 \mathrm{E}-09$ & $3.43 E-13$ & $1.26 \mathrm{E}-15$ & 8.94E-17 & $1.08 \mathrm{E}-15$ & $3.45 \mathrm{E}-13$ \\
\hline & $1.00 \mathrm{E}-03$ & 1.71E-05 & $9.17 \mathrm{E}-10$ & $3.36 \mathrm{E}-12$ & $2.39 E-13$ & $2.88 \mathrm{E}-12$ & $9.23 E-10$ \\
\hline & $1.00 \mathrm{E}-02$ & $1.24 \mathrm{E}-01$ & $6.65 \mathrm{E}-06$ & $2.44 E-08$ & $1.73 \mathrm{E}-09$ & $2.09 \mathrm{E}-08$ & $6.70 \mathrm{E}-06$ \\
\hline & $1.00 \mathrm{E}-01$ & $1.19 E+03$ & $6.40 \mathrm{E}-02$ & 2.34E-04 & 1.67E-05 & 2.01E-04 & $6.45 \mathrm{E}-02$ \\
\hline
\end{tabular}

NOTES: (1) Source: Table D-3 (last col.).

(2) (1) $\left(\mathrm{cm}^{3} / \mathrm{s}\right) \times 2.35 \mathrm{E}+02\left(\mathrm{Ci}\right.$, gap activity, Table D-3) / 4.38E+06 $\left(\mathrm{cm}^{3}\right.$,WP void Vol., Table D-1).

(3) $(1)\left(\mathrm{cm}^{3} / \mathrm{s}\right) \times 8.61 \mathrm{E}+00\left(\mathrm{Ci}\right.$, gap activity) $/ 4.38 \mathrm{E}+06\left(\mathrm{~cm}^{3}\right.$, WP void Vol) $\times 0.1$ (Leakpath factor).

(4) (1) $\left(\mathrm{cm}^{3} / \mathrm{s}\right) \times 6.13 \mathrm{E}-01\left(\mathrm{Ci}\right.$, gap activity) $/ 4.38 \mathrm{E}+06\left(\mathrm{~cm}^{3}\right.$, WP void Vol) $\times 0.1$ (Leakpath factor).

(5) $(1)\left(\mathrm{cm}^{3} / \mathrm{s}\right) \times 7.39 \mathrm{E}+00\left(\mathrm{Ci}\right.$, gap activity) $/ 4.38 \mathrm{E}+06\left(\mathrm{~cm}^{3}\right.$,WP void Vol) $\times 0.1$ (Leakpath factor).

(6) $(2)+(3)+(4)+(5)$.

Leakpath factor $=0.1($ Subsection 4.2 .18$)$ 
INTENTIONALLY LEFT BLANK 
APPENDIX E

CALCULATION OF RADIONUCLIDE CONCENTRATIONS IN RAISE 
INTENTIONALLY LEFT BLANK 


\section{APPENDIX E - CALCULATION OF RADIONUCLIDE CONCENTRATIONS IN RAISE}

The calculation of radionuclide concentrations in the emplacement drift ventilation raises is based on the average ventilation flow rate of $30 \mathrm{~m}^{3} / \mathrm{s}$ (Subsection 4.1.1), the WP volumetric leakage rate (Table D-2), the radionuclide source terms (Table 5) and the leakpath factor of 0.1 (Subsection 4.2.18). Table E-1 presents the calculation sheet for radionuclide source terms based on the assumption that $3 \%$ of fuel rods failed (Subsection 4.2.17). The calculation of radionuclide concentrations in the ventilation raise is presented in Table E-2.

Table E-1. Radionuclide Source Terms Calculation Sheet

\begin{tabular}{|c|c|c|c|c|}
\hline Nuclide & $\begin{array}{c}\text { (1) } \\
\text { Ci per WP }\end{array}$ & $\begin{array}{c}\text { Failed Activity } \\
\text { (Ci) }\end{array}$ & $\begin{array}{c}\mathbf{( 3 )} \\
\text { Gap Release } \\
\text { Fraction }\end{array}$ & $\begin{array}{c}\mathbf{( 4 )} \\
\text { Gap Activity } \\
\text { (Ci) }\end{array}$ \\
\hline $\mathrm{Kr}-85$ & $2.37 \mathrm{E}+04$ & $7.12 \mathrm{E}+02$ & $3.00 \mathrm{E}-01$ & $\mathbf{2 . 1 4 \mathrm { E } + 0 2}$ \\
\hline $\mathrm{Cs}-137$ & $8.63 \mathrm{E}+05$ & $2.59 \mathrm{E}+04$ & $2.00 \mathrm{E}-04$ & $5.18 \mathrm{E}+00$ \\
\hline $\mathrm{Sr}-90$ & $5.71 \mathrm{E}+05$ & $1.71 \mathrm{E}+04$ & $2.00 \mathrm{E}-04$ & $3.43 \mathrm{E}+00$ \\
\hline Pu-238 & $4.81 \mathrm{E}+04$ & $1.44 \mathrm{E}+03$ & $3.00 \mathrm{E}-05$ & $4.33 \mathrm{E}-02$ \\
\hline Pu-239 & $3.72 \mathrm{E}+03$ & $1.12 \mathrm{E}+02$ & $3.00 \mathrm{E}-05$ & $3.35 \mathrm{E}-03$ \\
\hline Co-60 (crud) & $4.93 \mathrm{E}+01$ & $4.93 \mathrm{E}+01$ & $1.50 \mathrm{E}-01$ & $7.39 \mathrm{E}+00$ \\
\hline
\end{tabular}

NOTES: (1) Source: Table 5, Subsection 4.2.16.

(2) (1) $\times 3 \%$ fuel rod failed (for $\mathrm{Kr}, \mathrm{Cs}, \mathrm{Sr}$ and $\mathrm{Pu}$ ) (Subsection 4.2.17) For crud (1) $\times 100 \%$.

(3) Source: Table 6, Subsection 4.2.17.

(4) (2) $\times(3)$. 
Table E-2. Ventilation Raise Radionuclide Concentration Calculation Sheet

\begin{tabular}{|c|c|c|c|c|c|c|c|c|}
\hline $\begin{array}{c}\text { WP } \\
\text { Internal } \\
\text { Temperature } \\
\left({ }^{\circ} \mathrm{C}\right)\end{array}$ & $\begin{array}{l}\text { 'Leak } \\
\text { Hole } \\
\text { Diameter } \\
\text { (cm) }\end{array}$ & $\begin{array}{c}(1) \\
\text { Volumetric } \\
\text { Leakage } \\
\text { Rate } \\
\left(\mathrm{cm}^{3} / \mathrm{s}\right)\end{array}$ & $\begin{array}{l}(2) \\
\mathrm{Kr}-85 \\
\mathrm{Conc} . \\
\left(\mathrm{Ci} / \mathrm{m}^{3}\right)\end{array}$ & $\begin{array}{c}(3) \\
\text { Cs-137 } \\
\text { Conc. } \\
\left(\mathrm{Ci} / \mathrm{m}^{3}\right)\end{array}$ & $\begin{array}{c}(4) \\
\text { Sr-90 } \\
\text { Conc. } \\
\left(\mathrm{Ci} / \mathrm{m}^{3}\right)\end{array}$ & $\begin{array}{c}(5) \\
\text { Pu-238 } \\
\text { Conc. } \\
\left(\mathrm{Ci} / \mathrm{m}^{3}\right)\end{array}$ & $\begin{array}{c}(6) \\
\mathrm{Pu}-239 \\
\text { Conc. } \\
\left(\mathrm{Ci} / \mathrm{m}^{3}\right)\end{array}$ & $\begin{array}{c}(7) \\
\text { Co-60 } \\
\text { (Crud) } \\
\text { Conc. } \\
\left(\text { Ci } / \mathrm{m}^{3}\right)\end{array}$ \\
\hline \multirow{5}{*}{300} & $1.00 \mathrm{E}-05$ & $3.87 \mathrm{E}-12$ & $6.29 E-18$ & $1.52 E-20$ & $1.01 \mathrm{E}-20$ & 1.27E-22 & $9.85 \mathrm{E}-24$ & $2.18 \mathrm{E}-20$ \\
\hline & $1.00 \mathrm{E}-04$ & 4.79E-09 & 7.77E-15 & $1.89 \mathrm{E}-17$ & $1.25 \mathrm{E}-17$ & $1.58 \mathrm{E}-19$ & $1.22 \mathrm{E}-20$ & $2.69 \mathrm{E}-17$ \\
\hline & $1.00 \mathrm{E}-03$ & 1.39E-05 & $2.26 \mathrm{E}-11$ & $5.49 \mathrm{E}-14$ & $3.63 \mathrm{E}-14$ & $4.59 \mathrm{E}-16$ & $3.55 \mathrm{E}-17$ & $7.84 \mathrm{E}-14$ \\
\hline & $1.00 \mathrm{E}-02$ & $1.05 \mathrm{E}-01$ & 1.71E-07 & 4.15E-10 & $2.75 \mathrm{E}-10$ & $3.47 E-12$ & $2.68 \mathrm{E}-13$ & $5.93 \mathrm{E}-10$ \\
\hline & $1.00 E-01$ & $1.02 E+03$ & 1.66E-03 & 4.02E-06 & $2.66 \mathrm{E}-06$ & 3.36E-08 & 2.60E-09 & $5.74 \mathrm{E}-06$ \\
\hline \multirow{5}{*}{350} & $1.00 \mathrm{E}-05$ & 4.27E-12 & $6.93 \mathrm{E}-18$ & $1.68 E-20$ & 1.11E-20 & $1.40 \mathrm{E}-22$ & 1.09E-23 & $2.40 E-20$ \\
\hline & $1.00 \mathrm{E}-04$ & 5.23E-09 & $8.50 \mathrm{E}-15$ & $2.06 \mathrm{E}-17$ & $1.36 \mathrm{E}-17$ & $1.72 E-19$ & 1.33E-20 & $2.94 \mathrm{E}-17$ \\
\hline & $1.00 E-03$ & 1.49E-05 & $2.41 E-11$ & $5.86 \mathrm{E}-14$ & $3.88 \mathrm{E}-14$ & $4.89 \mathrm{E}-16$ & $3.78 \mathrm{E}-17$ & 8.36E-14 \\
\hline & $1.00 \mathrm{E}-02$ & 1.11E-01 & $1.81 \mathrm{E}-07$ & 4.38E-10 & $2.90 E-10$ & $3.66 \mathrm{E}-12$ & $2.83 \mathrm{E}-13$ & $6.26 \mathrm{E}-10$ \\
\hline & $1.00 \mathrm{E}-01$ & $1.08 E+03$ & $1.75 \mathrm{E}-03$ & 4.23E-06 & $2.80 E-06$ & 3.54E-08 & 2.73E-09 & 6.05E-06 \\
\hline \multirow{5}{*}{500} & $1.00 \mathrm{E}-05$ & $5.32 \mathrm{E}-12$ & $8.64 \mathrm{E}-18$ & $2.10 \mathrm{E}-20$ & $1.39 \mathrm{E}-20$ & $1.75 \mathrm{E}-22$ & 1.35E-23 & $2.99 \mathrm{E}-20$ \\
\hline & 1.00E-04 & 6.39E-09 & $1.04 \mathrm{E}-14$ & $2.52 E-17$ & 1.67E-17 & 2.10E-19 & 1.63E-20 & $3.59 \mathrm{E}-17$ \\
\hline & $1.00 \mathrm{E}-03$ & 1.71E-05 & 2.77E-11 & $6.73 E-14$ & 4.45E-14 & $5.62 E-16$ & $4.35 E-17$ & $9.61 \mathrm{E}-14$ \\
\hline & $1.00 E-02$ & 1.24E-01 & $2.01 \mathrm{E}-07$ & $4.88 \mathrm{E}-10$ & $3.23 \mathrm{E}-10$ & $4.08 E-12$ & 3.16E-13 & 6.97E-10 \\
\hline & 1.00 E-01 & $1.19 \mathrm{E}+03$ & 1.94E-03 & $4.70 \mathrm{E}-06$ & $3.11 \mathrm{E}-06$ & 3.93E-08 & 3.04E-09 & 6.71E-06 \\
\hline
\end{tabular}

NOTES: Raise airflow rate $=30 \mathrm{~m}^{3} / \mathrm{s}$ (Subsection 4.1 .1 ).

WP void volume $=4.38 \mathrm{E}+06 \mathrm{~cm}^{3}$ (Subsection 4.1 .2 )

Leakpath factor $=0.1$ (Subsection 4.2.18)

(1) Source: Table D-2 (last col.).

(2) $(1)\left(\mathrm{cm}^{3} / \mathrm{s}\right) \times 2.14 \mathrm{E}+02\left(\mathrm{Ci}\right.$, gap activity, Table E-1)/4.38E+06 $\left(\mathrm{cm}^{3}\right) / 30 \mathrm{~m}^{3} / \mathrm{s}$.

(3) $(1)\left(\mathrm{cm}^{3} / \mathrm{s}\right) \times 5.18 \mathrm{E}+00\left(\mathrm{Ci}\right.$, gap activity, Table E-1) $/ 4.38 \mathrm{E}+06\left(\mathrm{~cm}^{3}\right) \times 0.1$ (Leakpath factor) $/ 30 \mathrm{~m}^{3} / \mathrm{s}$.

(4) (1) $\left(\mathrm{cm}^{3} / \mathrm{s}\right) \times 3.43 \mathrm{E}+00\left(\mathrm{Ci}\right.$, gap activity, Table E-1) $/ 4.38 \mathrm{E}+06\left(\mathrm{~cm}^{3}\right) \times 0.1$ (Leakpath factor) $/ 30 \mathrm{~m}^{3} / \mathrm{s}$.

(5) (1) $\left(\mathrm{cm}^{3} / \mathrm{s}\right) \times 4.33 \mathrm{E}-02\left(\mathrm{Ci}\right.$, gap activity, Table E-1) $/ 4.38 \mathrm{E}+06\left(\mathrm{~cm}^{3}\right) \times 0.1$ (Leakpath factor) $/ 30 \mathrm{~m}^{3} / \mathrm{s}$.

(6) (1) $\left(\mathrm{cm}^{3} / \mathrm{s}\right) \times 3.35 \mathrm{E}-03\left(\mathrm{Ci}\right.$, gap activity, Table E-1) $/ 4.38 \mathrm{E}+06\left(\mathrm{~cm}^{3}\right) \times 0.1$ (Leakpath factor) $/ 30 \mathrm{~m}^{3} / \mathrm{s}$.

(7) $(1)\left(\mathrm{cm}^{3} / \mathrm{s}\right) \times 7.39 \mathrm{E}+00\left(\mathrm{Ci}\right.$, gap activity, Table E-1) $/ 4.38 \mathrm{E}+06\left(\mathrm{~cm}^{3}\right) \times 0.1$ (Leakpath factor) $/ 30 \mathrm{~m}^{3} / \mathrm{s}$. 
INTENTIONALLY LEFT BLANK 